\title{
PRELIMINARY CONSIDERATIONS ON DEVELOPING IAEA TECHNICAL SAFEGUARDS FOR LMFBR POWER SYSTEMS
}

\author{
by \\ P. J. Persiani
}

\section{MASTER}

ARGONNE NATIONAL LABORATORY, ARGONNE, ILLINOIS

Prepared for the U. S. DEPARTMENT OF ENERGY under Contract $W-31-109-E n g-38$ 
Distribution Category:

Sa feguards-Nuclear Materials

Security (UC-15)

ANL-80-69

ARGONNE NATIONAL LABORATORY

9700 South Cass Avenue

Argonne, Illinois 60439

\section{PRELIMINARY CONSIDERATIONS ON \\ DEVELOPING IAEA TECHNICAL SAFEGUARDS \\ FOR LMFBR POWER SYSTEMS}

by

P. J. Persiani

Applied Physics Division

with contributions from:

J. P. Holmes, Sandia Lab.

J. L. Todd, Sandia Lab.

J. M. de Montmollin, Sandia Lab.

W. A. Higinbotham, BNL

E. V. Weinstock, BNL

C. D. Bingham, NBL

E. A. Hakkila, LASL
J. R. Dietz, LASL

G. J. Alkire, HEDL

C. K. Day, HEDL

N. C. Hoitink, HEDL

K. E. Freese, ANL

F. E. LeVert, ANL

B. S. Yarlagadda, ANL

September 1980

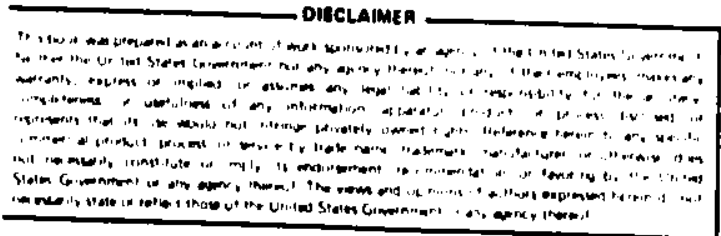

Work performed under the auspices of the Office of Safeguards and Security

U. S. Department of Energy 


\section{PREFACE}

A prime consideration in the international deployment of the fast breeder power system is safeguards. This preliminary report addresses technical sífeguards and assesses the current and developing safeguards technioues and systems consistent with the deployment of fast breeder power systems and reprocessing methods. 
I. INTRODUCTION .................... 2

II. ANALYSIS OF SAFEGUARDS CONSIDERATIONS ASSOCIATED WITH THE

FBR FUEL CYCLE . . . . . . . . . . . . . . . . 4

A. FBR Reactor Power Plant System . . . . . . . . . . 4

B. Transportation ................ . . 4

C. Reprocessing-Conversion ............... 12

D. Fuel Assembly Fabrication Facility ............ 13

E. Storage of FBR Spent Fuel and Blanket Assemblies . . . . . 15

III. IAEA SAFEGUARDS ...................... . 18

A. Objectives and Goals ................. . 18

B. Baslc Assumptions in IAEA Safeguards . .......... 19

C. Current IAEA Safeguards ................. 19

D. Advanced IAEA Safeguards . . . . . . . . . . . . 22

IV. METHODS FOR ACHIEVING IAEA SAFEGUARDS . . . . . . . . . . 24

A. Transition Perlod . . . . . . . . . . . 24

A.1 LWR Spent Fuel in Storage and Rerrocessing for FBR Use . 24

A.2 FBR Spent Fuel Reprocessing ............. 30

A.3 Direct F1ssile Materlal Accountabllity in Fresh

and Spent Fuel Storage ............ . 30

A.3.1 Isotopic Safeguards Techniques . . . . . . 34

A.3.2 Microsample Preparation .......... 34

B. FBR Fuel Cycle Phase .................. 35

B.1 FBR Power Plant Safeguards . . . . . . . . 35

B.1.1 Item Accountability ............ 35

B.1.1.1 Ultrasonic: Under Sodium Viewing

Systems . . . . . . . . . 36

B.1.1.2 Mechanical: Under-Sodium Reader ... 36

B.1.1.3 A Mult1layer Fully Encapsulated Self-

Powered Direction Gamma Monitor for

Use In Spent Fuel Storage Facilities . 36

B.1.2 Contalnment/Survelllance . . . . . . . 38

B.1.3 IAEA Inspection ............... 38

B.1.4 NDA Techniques ............... 39 
B.2 Reprocessing and Converston . . . . . . . . . . 39

B.2.1 Material Accountancy ............ . 40

B.2.1.1 Nondestructive Assay ........ . .40

B.2.1.2 Analytical Chem1stry Assay . . . . . .44

B.2.1.3 Measurement Precision and Accuracy . . .46

B.2.1.4 Conversion Facility ......... . .47

B.2.2 Isotope Correlations and Measurement Techniques. . .47

B.2.2.1 lsotope Correlation ......... . .47

B.2.2.2 Measurement Systems ......... .48

B.2.3 Containment and Surveillance ......... . .48

B.2.4 Impact on Safeguards Techniques from High

Burnups, Sodium, and Radiation Spiking ... . . 48

B. 3 MoX Fabrication and Scrap Recovery . . . . . . . . 49

B.4 Bulk Plutunium Storage and Intraplant Transportation . . 49

B.5 Application of IAEA Safeguard, During Transportation . . .50

B.5.1 Perlodic Shipping/Receiving Comparison ..... . 50

B.5.2 IAEA Escorts .............. . . . . . .

B.5.3 Remote Survelllance ........... . . . . . 51

v. ADVANCED IAEA SAFEGUaRdS RESEARCH AND DEVELOPME.IT . . . . . . . 52

A. Materials Control anc' Accountancy . . . . . . . . . 53

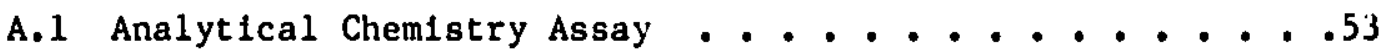

A.2 Advanced NDA Techniques for Safeguards Systems . . . . .53

B. Contalnment/Survelllance . . . . . . . . . . . 54

B.1 Crane Monitor System . . . . . . . . . . . . 54

B.2 Storage Acoustic Monitor ... . . . . . . . . 54

B.3 Fuel Assembly Identification Devices (FAID) . . . . . .54

B.4 Under-Sodium Viewing (USV) System . . . . . . . . . .54

B.5 Other Systems for further Development . . . . . . . .54

C. Input Measurements .................. . . . . .

D. On-Line, Near-Real-Time IAEA Advanced Safeguards System . . .55

E. Description of Reference Advanced Safeguards System . . . . .57

F. Implementation of the Safeguards System ...........63

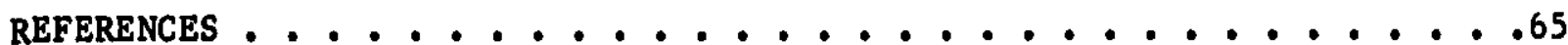




\section{LIST OF FIGURES}

No.

1. Sketch of Reference FBR Primary System . . . . . . . . . 6

2. Diagram of Annual Pu Fuel Mass Flow for Reference LMFBR . . . . . 7

3. Reference FBR Fuel Handling System ................ 11

4. Reference FBR Fuel PIn and Fuel Assembly ............ . 14

5. Diagram of Annual Fuel Mass Flow for Reference PWR . . . . . 25

6. Unirradiated and Irradiated Fuel Storage Monitoring . . . . . . 28

7. Facility Data Collection Module Computer System . . . . . . 29

8. LWR Reprocessing Flow Diagram (kg/day) . . . . . . . . . 31

9. FBR Core and Blanket Reprocessing Flow Dlagram (kg/day) . . . . 32

10. Under-Sodium Vlewing System for FFTF/LMFBR. . . . . . . . . . 37

11. Conceptual Overview Contalnment and Survelllance System . . . . 56

12. Tamper-Indj.cating Techniques. . . . . . . . . . . . 58

13. Tamper Indicating Sensor Module . . . . . . . . . . . 59

14. Closed Circult T.V. . . . . . . . . . . . . 61

15. Data Collection Module Data Flow. . . . . . . . . . . 62

16. Central Monitoring and Display Module Data Flow . . . . . . . 64 


\section{LIST OF TABLES}

No.

Title

$\underline{\text { Page }}$

I. Core and Fuel Specifications for Typical LMFBR Reactor . . . . 5

II. Annual Fissile Mass Flow In Typical LMFBR Reactor . . . . . 8

III. Nominal Uranium and Plutonium Content in Typical LMFBR Fuel Assembly . . . . . . . . . . . . . . . . . 9

IV. Fuel Handling and Storage for Typical FBR Reactor . . . . . 10

V. Estimated World Spent Fuel Arisings . . . . . . . . . 16

VI. Niantities of Safeguards Significance . . . . . . . . 20

VII. Guidelines for Estimated Material Conversion Times . . . . . 21

VIII. Relative Magnitudes of Spent-Fuel Item-Accountability Tasks for equivalent Quantities of Contained Plutcnium . . . . . 26

IX. Key Measurement Points (KMP) Typical Flows and Diversion Possibilities for 200 tonnes/yr FBR Core and Blanket Reprocessing Plant .................. 33

X. NDA Methods for Nuclear Material Accountability . . . . . . 4 41

XI. Possible NDA Applications for Reprocessing Plant Solutions . . 43

XII. Application of Chemical Assay Procedures . . . . . . . 45 
PREL IMINARY CONSIDERATIONS ON DEVELOP ING IAEA TECHNICAL SAFEGUARDS FOR LMFBR POWE!' SYSTEMS

by

P. J. Persiant

\section{ABSTRACT}

Nuclear fuel cycles safeguards should be considered in the dynamic context of a world deployment of various reactor types and varying availability of fuel-cycle services. This is particularly true of the fast breeders, which must be fueled in the transition period with fissile material produced by other types of reactors. There will be a close and controlled interaction between thema1reactor cycles and the future deployment of breeders that will be critically dependent on the plutonium produced in those cycles. The quantities of plutonium and the reprocessing, conversion, fabrication, and storage methods of the fuel for the fast breeders will have a signiflcant impact on safeguards techniques. The approach to the fast breeder fuel. cycle safeguards follows the general safeguards sy stem approach proposed by the IAEA. The objective of IAEA safeguards is the timely detection of diversion of significant quantities of muclear material and deterrence of such diversion by the risk of early detection. The goal requires the development of highly effective safeguards systems that are both technically and publicly credible. To achleve independent verification of material balance accountancy requires the capability to monttor inventory status and verify material flows and quantities of all nuclear materlals subject to safeguards. Contalment and survelllance measures are applied to facilitate monttoring at key measurement points, malntain integrity of material balance, and complement materfal accountancy to effect the timely detection of diversion of significant quantities of nuclear material. The safeguards study attempts to develop a generic reference IAEA Safeguards System and explores varlous system options using containment/surveillance and material accountancy instrumentation and integrated systems designs. 


\section{PREL IMINARY CONS IDERATIONS ON DEVELOPING IAEA TECHNICAL SAFEGUARDS FOR LMFBR POWER SYSTEMS}

\section{INTRODUCTION}

A prime consideration in the international deployment of the fast breeder power system is safeguards. This preliminary report addresses technical safeguards (near real-time material accountability, containment/surveillance measures, and Integ rated System concepts) and assesses the current and developIng safeguards techniques and systems consistent with the deployment of fast breeder power systems and reprocessing methods.

Nuclear fuel cycles safeguards should be considered in the dynamis context of a world deployment of varlous reactor types and varying availability of fuel-cycle services. This is particularly true of the fast breeders, which must be fueled in the transition period with fissile material produced by other types of reactors. There will be a close and controlled interaction between thermal-reactor cycles and the future deployment of breeders that will be critically dependent on the plutonlum produced in those cycles. The quantities of plutonium and the reprocessing, conversion, fabrication, and storage methods of the fuel for the fast breeders will have a significant impact on safeguards terhniques. The plutonium throughput, high fissile content and the use of sodium coolant in the FBR cycle may require additional safeguards techniques development beyond those of the thermal cycle.

The approach to the fast breeder fuel cycle safeguards lollows the gene ral safegui.rds system approach proposed by the IAEA. The objective of IAEA safeguards is the timely detection of diversion of significant quantities of nuclear material (see Table VI) and deterrence of such diversion by the rlsk of early detection. The goal requires the development of highly effective safeguards systems that are both technically and publicly credible. Ideally, to achieve 1 ndependent verification of material balance accountancy requires the capability for near real-time monitoring of inventory status and verifylng material flows and quantitles of all nurlear materials subject to safeguards. In addition, contalnment and surveillance measures arc applied to facilitate monitoring at key measurement points, maintain integrity of material balance, and complement material accountancy to effect the timely detection of diversion of significant quantities of nuclear material (see Table VI).

Terhnology and subsystem components include measurement methods and inst rumentation, process monttoring and control instrumentation, data management and analysis methodology, and contalnment ind surveillance techniques. Nuclear material flow verification objectives c.in be achieved by developing and applying advanied safeguards systems with emphasis on the independence of measurement $s$ by the IAEA. Safeguards techniques that are currently avallable and are assessed to be directly applicable to the fast breeder cycle, will form the basis of the IAEA FBR safeguards system.

The capability for continuous or near real-time monitoring of nuclear material during all processing and transfer operations is a desireable objective. Advanced automated safeguards systems initially designed into nuclear facilities may facilitate effective international safeguards by providing timely and sensitive information on inventory status. 
The IAEA presently implements a safeguards system for periodic material accountancy and a set of contaiment and survelllance measures. The proposed advanced technical safeguards will allow the current IAEA Safeguards System to incorporate a near real-time level capability for the timeliness criterion. The proposed safeguards techniques include components which are commercially available, or in the laboratory testing phase of development, or in the conceptual stage of development. It is expected that the implementation of the se proposed technical safeguards will be initially integrated into the fuel storage phase of the fuel cycle during the transition period from the thermal system to the FBR system.

The safeguards study attempts to develop a generic reference IAEA Safeguards Sy stem and explores various system options. using contal nment/ survelilance and material accountancy inst rumentation and integrated systems designs. This report is structured into the following categories: Section II - Analysis of Safeguards, briefly analyzes the safeguards considerations which are primarily characteristic of the fast breeder fuel cycle sytem; Section III - IAEA Safeguards, reviews the current IAEA safeguards goals and objectives; Section IV - Methods for Achieving IAEA Safeguards, describes the methods and systems identified for achleving IAEA safeguards objectives; and Section V - Advanced IAEA Safeguards Re search and Development, introduces proposed integrated and advanced IAEA safeguards systems and identifies the Rrs search and Development programs necessary for the implementation of these systems. 


\section{ANALYSIS OF SAFEGUARDS CONSIDERATIONS ASSOCIATED WITH FBR FUEL CYCLE}

In the context of assessing the safeguards concerns relating to Fast Breeder Reactors (FBR), the reference system selection was based on the current state of development, design, construction, deployment, operating data and experience which reflects the state of the breeder technology for the first-generation of commerclal power systems. The major power breeder programs recelving international-level development support are the liquid-metal cooled reactor systems utillzing the uranium-plutonium mixed-oxide fuel cycle. The commercial-scale systems under construction are: France, ${ }^{1}$ Super Phenix Plant; USSR, ${ }^{2} \mathrm{BN}-350$ and -600 ; and the United Kingdom, 3 Commercial Fast Breeder, CFR (in design). The advanced phase of the SuperPhenix reactor design and construction allows specific modeling of the reference system for each major stage of the total operational plant system.

The safeguards concerns are addressed to the major stages of the FBR fuel cycle. The reactor power plant stage includes the annual mass flow in unit fuel and blanket assemblies, storage of $\mathrm{fresh}$ and spent fuels, and loading and unloading systems. The transportation stage considers fuel and blanket assemblies, bulk forms of material in canisters and the modes of transport (sea, air, land). The reprocessing-conversion stage involves the processing of LWR spent fuel. assemblies during the transition into the deployment of breeder systems and the reprocessing of FBR spent fuel and blanket assemblies. The fabrication stage includes fuel element and fuel assembly manufacturing. The storage stage of the fuel cycle includes the storage of FBR fuel and blanket assemblies during the LWR to FBR transition period, and the LWR spent-fuel storage facilities.

\section{A. FBR Reactor Power Plant System}

In the normal operating mode of $f a s t$ breeder power reactors, the basic unit of one fuel assembly and one blanket assembly is assumed applicable for item accountability. Table I and Fig. 1 include the reference reactor specifications and design characteristics. Typical mass and fuel assembly flows are schematically shown in Fig. 2 and listed in Tables II and III. Table IV and Fig. 3 describes the general design features of the storage facility and the loading and unloading sequence of fresh and spent fuel assemblies.

Fuel assemblies removed from the core are passed from the sodium transfer tank to the rotating storage drum, as shown $1 \mathrm{n}$ Fig. 3. The decay heat of the assemblies is removed by two independent sodium systems connected to sodium-to-air heat exchangers. Th assemblies are transferred into the storage drum from the loading ramp by means of a rotating plug and a fuel transfer gripper. Subsequent steps in the fuel handling procedure are: extraction from the storage drum to the conditioning room via a handing cell, (2) preparation for shipment in the conditioning room, transfer to shipping casks, which are filled with sodium and sealed, and (3) transfer of casks to a transport passageway under the cask-loading station.

\section{B. Transportation}

To introduce a practical timing perspective to the transport safeguards for the FBR fuel cycle, the near-term French program plan ${ }^{4}$ is used 
TABLE I. Core and Fuel Specifications for Typical LMFBR Reactor

\begin{tabular}{|c|c|}
\hline Rated Output & $\begin{array}{lr}\text { Gross Thermal } & 3000 \mathrm{MW} \\
\text { Gross Electrical } & 1260 \mathrm{MW} \\
\text { Net Electrical } & 1200 \mathrm{MW} \\
\text { Station Use } & 4.8 \%\end{array}$ \\
\hline Net Efficiency & $40 \%$ \\
\hline Conversion Ratio & 1.2 \\
\hline Core Shape and Size & $\begin{array}{l}\text { Hexagonal, } 350-\mathrm{cm} \text { Equivalent Diameter } \\
100 \mathrm{~cm} \mathrm{High}\end{array}$ \\
\hline$\therefore$ ober of Fuel Channels & 358 Fuel Channels in Two Zones \\
\hline $\begin{array}{l}\text { Gore Loading at Rated } \\
\text { Power }\end{array}$ & $5900 \mathrm{~kg} \mathrm{PuO}, 2$ and $30100 \mathrm{~kg} \mathrm{UO}$ \\
\hline $\begin{array}{l}\text { Average Power Density in } \\
\text { Fuel }\end{array}$ & $508 \mathrm{dw} / \mathrm{kg} \mathrm{PuO}_{2}$ \\
\hline $\begin{array}{l}\text { Average Core Power } \\
\text { Density }\end{array}$ & $300 \mathrm{~kW} / 1 \mathrm{iter}$ \\
\hline Burnup & Initial $70000 \mathrm{MWd} / \mathrm{t}$ \\
\hline $\begin{array}{l}\text { Fuel Form and } \\
\text { Composition }\end{array}$ & $\begin{array}{l}\text { Mixed Oxide }\left(\mathrm{PuO}_{2}-\mathrm{UO}_{2}\right) \text { Annular Pellets, } \\
7.02 \mathrm{~mm} \text { o.d., In Stainless Steel Tubes } \\
8.65 \mathrm{~mm} 0 . \mathrm{d} ., \times 2700 \mathrm{~mm} \text { Long } \\
\mathrm{PuO}_{2} \text { Enrichments, Inner Zone } 14.6 \% \\
\text { Outer Zone } 18.5 \%\end{array}$ \\
\hline Cladding & $\begin{array}{l}\text { Type } 316 \text { Stalnless Steel Tube, } 8.65 \mathrm{~mm} \\
\text { o.d., with Spacer Wire Helically Wound } \\
\text { Around Pin }\end{array}$ \\
\hline Fuel Assembly & $\begin{array}{l}\text { Hexagonal Assembly, } 173 \mathrm{~mm} \text { Across Flats, } \\
\text { Holds Bundle of } 271 \text { Fuel PIns } \\
\text { Total Length of Assembly is } 5400 \mathrm{~mm}\end{array}$ \\
\hline Coolant & Sodium \\
\hline
\end{tabular}




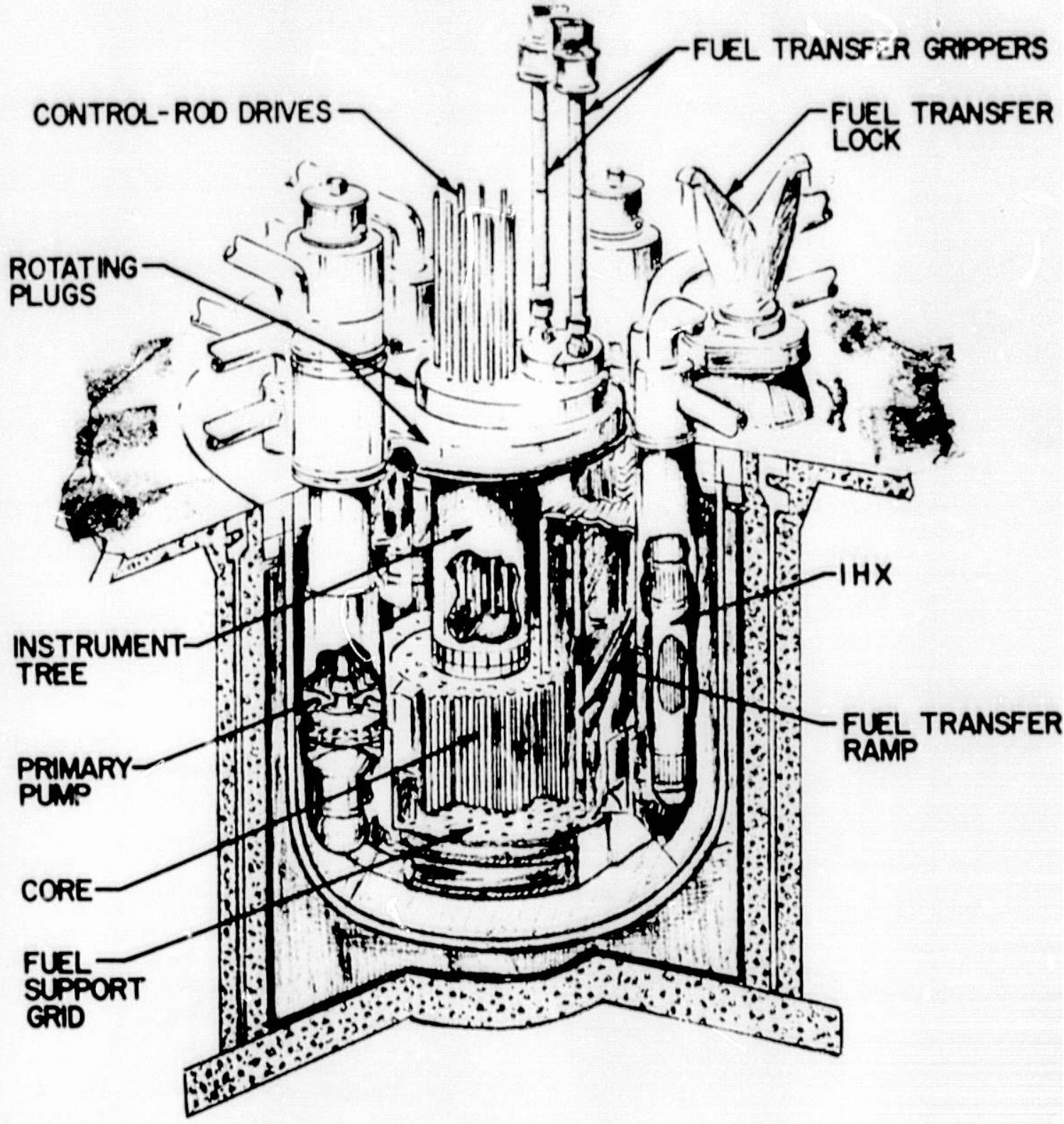

Fig. 1. Sketch of Reference FBR Primary System. 
ANMULAL PU FLEL MISS FLOW DIAGRAMS FOR REFERE!'CE TH' .MFBR

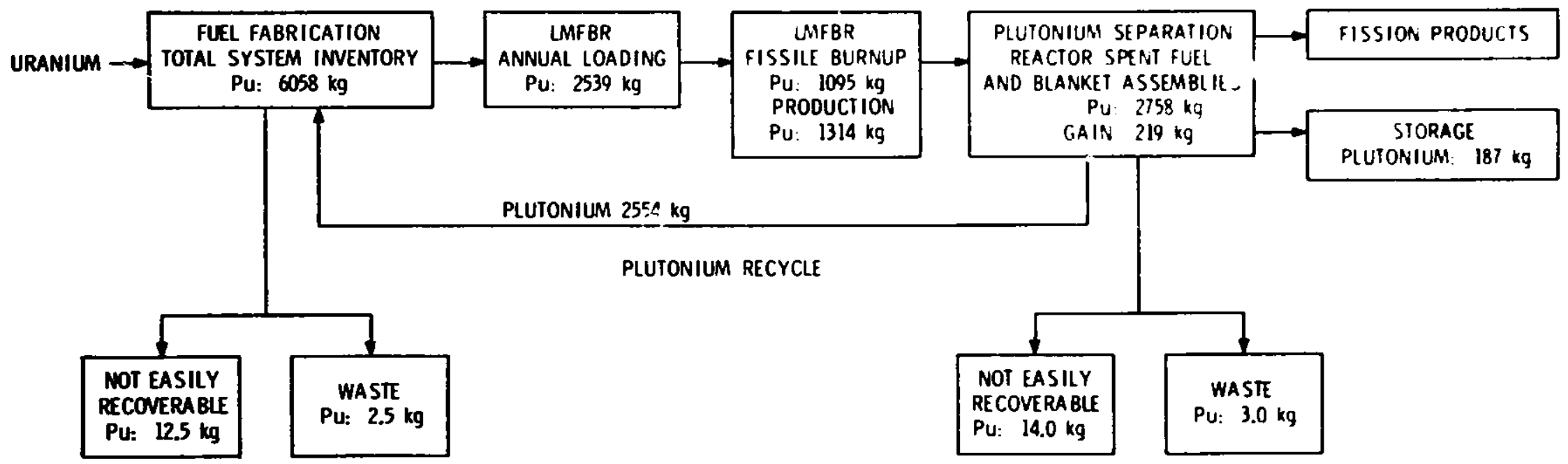

Fig. 2. Diagram of Annual Pu Fuel Mass Flow for the Reference LMFBR. 
TABl.E 11. Annual Fissile fuel Mass flow in Typical LMFBR Reactor

\begin{tabular}{|c|c|c|}
\hline fuel Cycle & \multicolumn{2}{|c|}{$\mathrm{Pu} / \mathrm{U}$} \\
\hline Composition & \multicolumn{2}{|c|}{$\begin{array}{l}10.37 \times \mathrm{Pu} / \mathrm{HM} \\
0.2 x^{2} 23 \mathrm{~S} / \mathrm{U}\end{array}$} \\
\hline Total HM (kg) & $\begin{array}{l}\text { (Core) } \\
15575\end{array}$ & $\begin{array}{c}\text { (Blanket) } \\
\text { isluo }\end{array}$ \\
\hline \multicolumn{3}{|l|}{ Cha rge $(\mathrm{kg})$} \\
\hline $\begin{array}{r}23 S_{U} \\
\mathrm{Pu}\end{array}$ & $\begin{array}{l}16.1 \\
2539\end{array}$ & $\begin{array}{c}30.2 \\
-\end{array}$ \\
\hline \multicolumn{3}{|l|}{ D1 scharge $(\mathbf{k g})$} \\
\hline${ }^{233_{U}}$ & $\begin{array}{l}16.1 \\
2399\end{array}$ & $\begin{array}{r}29.3 \\
359\end{array}$ \\
\hline
\end{tabular}

${ }^{a} 1 / 2$ of core annually

HM; Heavv Metal 
TABLE 111. Nom1nal Uranium and Plutonium Content in Typical LMFBR Fuel Assembly

\begin{tabular}{cc}
\hline fuel cycle & Pu/U \\
\hline Composition & $\begin{array}{l}16.37 \text { Pu/HM } \\
0.2 x^{23} / \mathrm{U}\end{array}$ \\
\hline Total HM (kg) & 87 \\
\hline Charge (kg) & \\
$235 U$ & 0.15 \\
Pu & 14.2 \\
\hline Discharge (kg) & \\
$235 U$ & 0.09 \\
Pu & 13.4 \\
\hline
\end{tabular}


TABLE IV. Fuel handling and Storage for Typical FBK Reactor

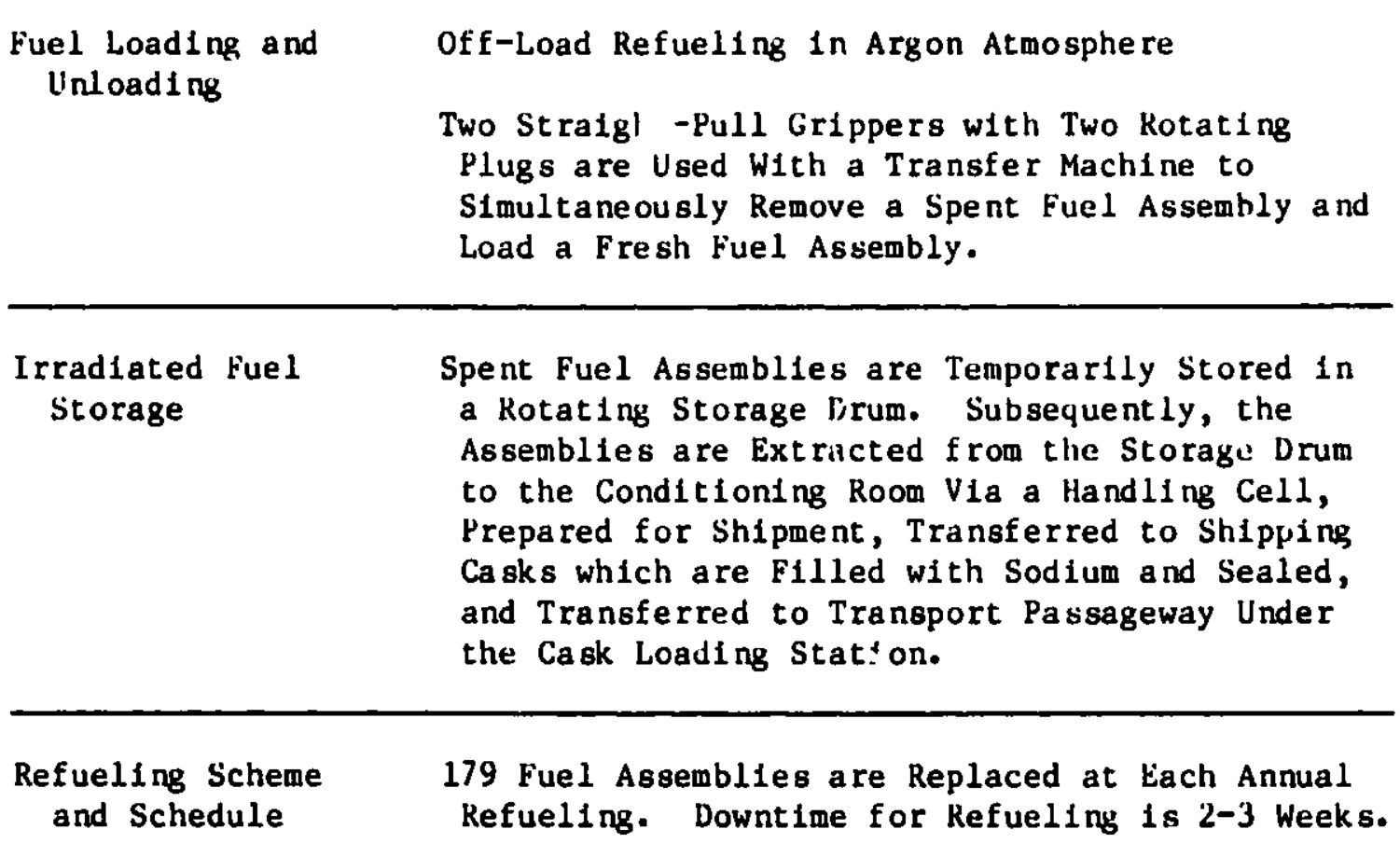




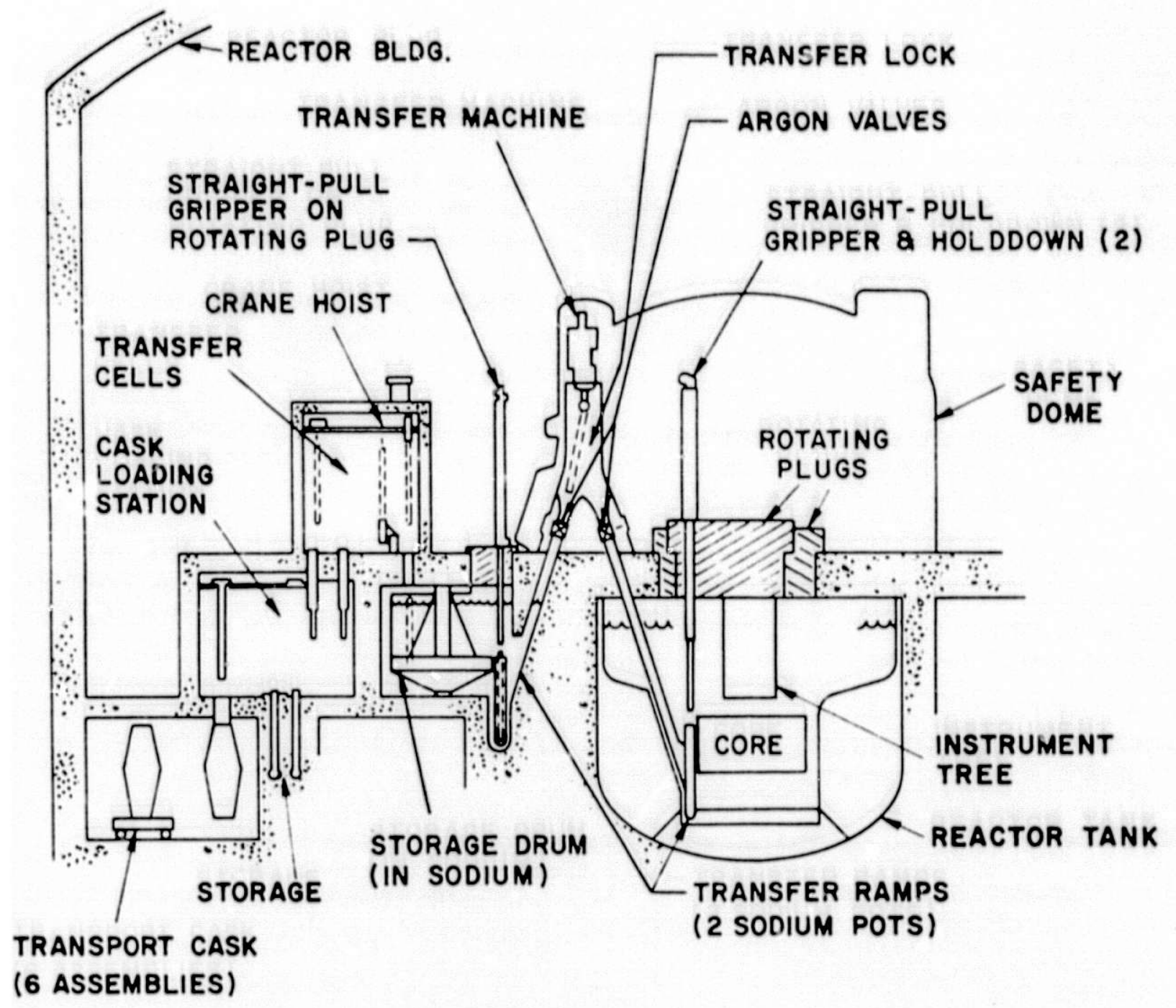

Fig. 3. Reference FBR Fue1 Handling Systems. 
as a guide. The plan, as outlined in Ref. 4, is to bulld one to three breeder reactors within the 1980 - 1985 period, and then one $1200-\mathrm{MWe}$ reactor each year from 1.986 to 1996. This program implies that safeguards : : considered in the near-term disposition with respect to location of reprocessing plants for the LWR spent fuel assemblies and the FBR fuel-fabrication plants. The deployment of $F B^{\prime} s$ during the transition period from the LWR to the FBR fuel cycle system, would probably not include colocation of power reactors, fabrication piants, and reprocessing plants. Safeguards would have to be given high priority during the transportation of bulk mixed-oxide fuel between the reprocessing plant and the fabrication facllity as well as the transportation of tresh and spent fuel assemblies.5 In this phase of transportation, item accountability is expected to be the primary technique of safeguards for the shipper-recelver transfers. Non-destructive assay (NDA) and physical signatures would have to be developed for the specific mode in which the bulk container and FBR assemblies are packaged for transport. The NDA techniques that are currently belng developed should be assessed for utilization on FBR assemblies which may or may not contain sodium. Containment and survelllance techniques may be utilized to provide a more real time measure of the custody, location and integrity of the nuclear material in transit.

In the bulk mixed-oxide fuel, the NDA and physical signature identication methods may be effectively supplemented by chemical and nuclear analyticaj. assay techniques for fissile accountability.

On the basis that mixed-oxide fuel will be transported off-site on a global scale in bulk form or as fuel assemblies, the three modes of transportation (land, sea, and air) should be factored into the safeguards considerations, which would include:

a. Land transportation would require development of transport cask units sized for highway load limits, and larger units may be scaled for rall or water transport.

b. Sea transportation must be considered since reprocessing plants for LWR fuel in various fuel centers wonld shlp fabricated and/or bulk mixed-oxide fuel to deployed power reactors or fabrication factlities in, and would ship fabricate $d$ mixed-oxide fuel to other countries.

c. Protection against national diversion would need to be emphesized. Enroute reporting of seal integrity, identification, and location should be considered for development in long-distance shipments.

d. Alr transport (e.g. through the use of heliocop'ers) would decrease the transport time of nuclear material in fresh assemblies or bulk form.

\section{Reprocessing-Conversion}

Chemical separations plants 6,7 are the most complex of the nuclear fuel-cycle facilities requiring safeguards. The fuel-reprocessing or chemical separations plant confronts the safeguards system designer with large quantities of fissile materials in several forms, in various phases of manufacture, 
and Introduces nuclear material flow verification measurement requirements ranging from highly radloactive and dilute spent-fuel feed material to a high-purity, concentrated fissile product. The facilitles present the need for material balance measurement sensitivities to maintain a high level of material accountancy verification. To develop the most effective safeguards system in the chemical separation plant, all avallable safeguards techniques must be optinfized and integrated.

Facilities designed for recovery of enriched uranium residuals, for comrecovery of the uranium and plutonium, for breeder-reactor fuels production, or for separation of the transuranic elements from the spent fuel for storage or future disposition, will all have a common requirement for effective safeguards. Generally the safeguards systens will not differ greatly.

In general, the reprocessing of $U-P u$ fuel in the Purex system begins with spent fuel receiving, unloading, and intermediate storage in a poul. The headend process consists of mechanical shearing, dissolution of the nuclear fuel in nitric acid, the solvent extractive separation of U-Pu with co-decontanination of fissiun product, and plutonium and uranium partition followed by further purification of the respective streans. The deployment of I'BR would require a more specific reprocessing design to accomodate FBR spent fuel.

The requirement for timely detection of non-verification of material balance involving small quantities of material has led to the development of automated systems for near-real-time measurements and control of fissile materials. Pasisive and active gamma-ray, $x-r a y$, and neutron interrogation methods for nondestructive assay (NDA) determinations are the primary techniques used in material-control systems. When coupled with the continuously developing chemical and nuclear analytical methods, these measures comprise the safeíuards technique of fissile-material balance accountability and control for detecting non-verification of fissile material balance in an acceptable timely mode.

The containment and survelllance systems of safeguards are necessary complementary measures in maintaining integrity of material accountancy measures, in detecting anomalies in nuclear materfal flows and/or inventories in the fuel cycle facilities. Containment and survellance adds an overlaytr of timeliness of detection when coordinated with materials accountancy.

\section{Fuel Assembly Fabrication Facility}

The fabrication 8,9 of plutonium fuel involves the welghing and mixing of $\mathrm{PuO}_{2}$ and $\mathrm{UO}_{2}$ powder, fabrication into pellets and fuel pin elements, and finally emplacement into fuel assemblies, see Fig. 4. The primary safeguards system throughout this phase of the fuel cycle process would involve item accountability, process monitoring and fissile content measurements by NDA techniques. Physical and nuclear signatures as well as tamper-indicating seals on the finished fuel assembly units would constitute the survelilance and control aspect of safeguarding for the remainder of the fuel cycle flow. These subsequent stages would consist of temporary storage, transport to reactor location (probably in dry transport casks) and assembly preparation for Insertion into the sodium environment, and into reactor storage pool for eventual loading into the reactor core. The verification of assembly identity 


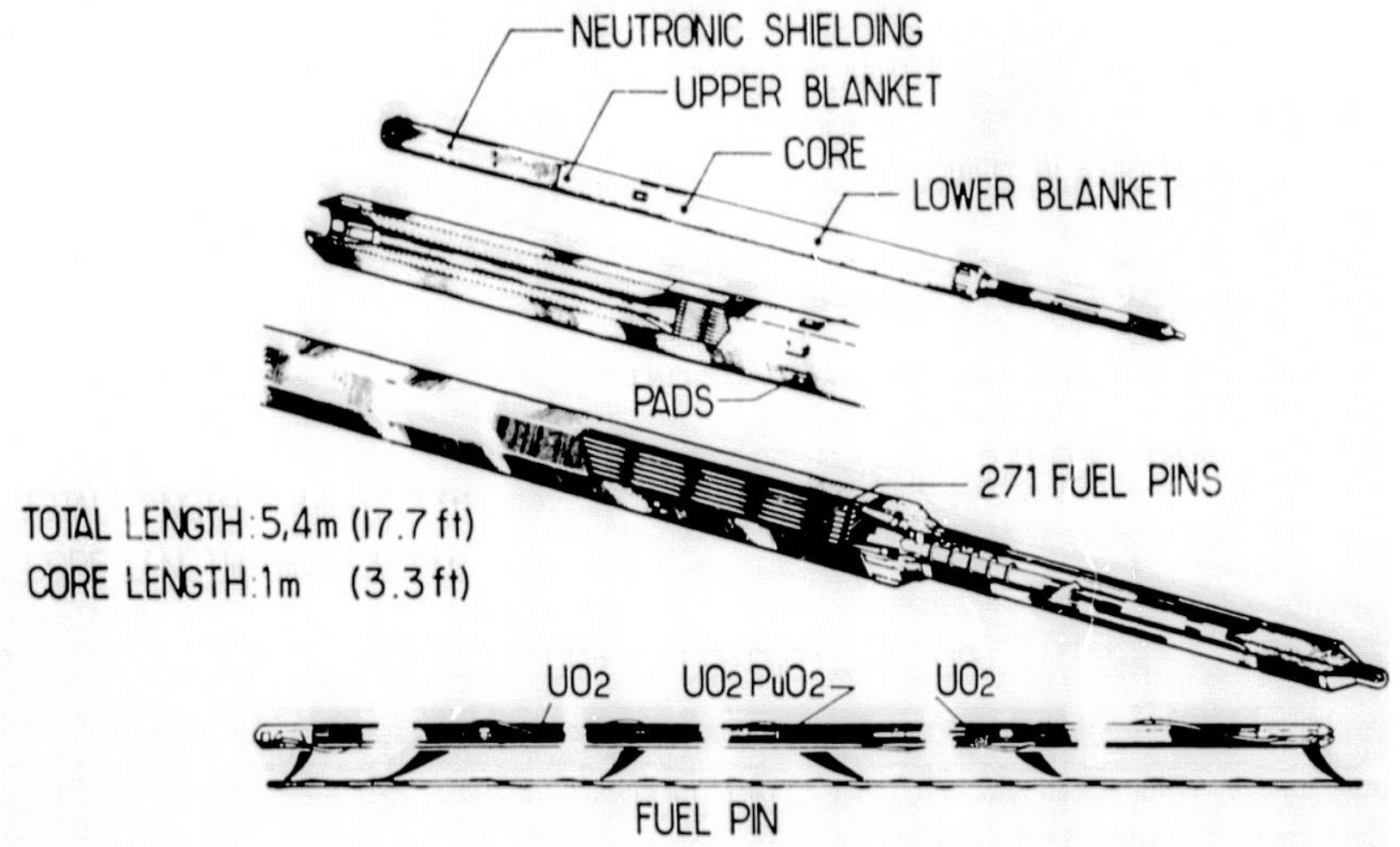

Fig. 4. Reference FBR Fuel Pin and Fuel Assembly. 
and storage or core location under sodiun can be affected by ultrasonic techniques now in the process of advanced development. Of particular note, the fissile material is in the form most suitable for iten accountability for most of its lifetine (years) in the fuel cycle. The perfod during which it exists in aqueous form, that is in the reprocessing and conversion phase, nay be days or weeks compared to years in the iten accountably forn during the fabrication, storage and in-situ radiation phases of the tctal power plant cycle. Therefore, to supplement iten accountability with nuclear Taterial identification and accountability, the fuel assembly and canlster units should Include design features which would allow sampling for NDA or clienical assay measurements.

\section{E. Storage of FBR Spent Fuel and Blanket Assenblies}

In the LWR to FBR transition phase, the primary fuel feed would be derived fron the reprocessing of LWK spent fuel. During this phase the FBK spent fuel and blanket assenblies will be placed in a storage pool. This pool may be colocated with the reactor plant complex but nol necessarily within the reactor system, unless FBR systens acconnodate spent fuel storage at greater capacities than the nurnal operational annual reloading schedules. Fron Table II, the reference FBR spent fuel storage requirements tor the initial reactor over 1980 1995 would involve approxinately 240 tonnes $U$ ( 36 tonnes of plutoniun) from the core assenblies and 240 tonnes $U$ ( 5 tonnes of plutunium) from the blanket assemblies. Assuming a deployment of about 10 - 15 FBR systens over 1985 - 199' the total storage requirenents would involve about a total of 100 annual reactor loadings or 1600 tonnes $U$ ( $24 U$ tonnes of plutoniun) fron the core and 1600 tonnes $U$ (36 tonnes of plutoniun) tron the blankits.

W1th the gradual introduction of a breeder technology there will be a significant and accelerating flow if epunt LWR and HWR fuel from reactor to storage. Fron Table $V$, the spent fuel in storage world-wide contains about 50 tonnes of plutonfum and that amount is currently growing at about 18 tonnes per year. As the nuclear econony evolves from only thermal reactors to a mix of thermal and breeder reactors, the fuel for the breeders will initially be manufactured in a process that uses the spent thermal reactor fuel as feedstock for development of a breeder. There will be accunulated tens of years of feedstock for a reprocessing cycle using spent thermal reactor fuel to manufacture fresh breeder reactor fuel. Such a process would require significant nodification of facilities to allow the use of spent FBR fuel as feedstock. There nay be a transition period of a decade or more during which tens of thousands of tonnes of spent thermal reactor fuel will be recycled to produce fuel for breeder reac ors with the breeder fuel placed into interim storage. The fuel for each breeder reactor will require the entire plutonium content from the spent fuel of approxinately 14 LWRs.

Planning for the transition from a thermal reactor econony to a breeder economy nust therefore include planning for storage of spent breeder reactor fuel. Current design plans for FBR's include only very limited on-site storage and no AFR storage. These plans must reflect the need for a gradual and snooth transition. Although spent breeder reactor fuel has an order of magnitude higher $P u$ content than spent thermal reactor fuel, the sane contalnment/ surveillance, 1tem accountability, and tamper-indicating methods will be used as safeguards techniques. The safeguards system design 
TABLE V. Estimated World Spent Fuel Arisings

\begin{tabular}{|c|c|c|c|c|}
\hline \multirow[b]{2}{*}{ Year } & \multicolumn{2}{|c|}{$\begin{array}{c}\text { Annual } \\
\text { (tonnes/yr) }\end{array}$} & \multicolumn{2}{|c|}{$\begin{array}{c}\text { Cumulative } \\
\text { (tonnes) }\end{array}$} \\
\hline & Uranium & Plutonium & Uranium & Plutonlum \\
\hline 1977 & 2200 & 18 & 6200 & 50 \\
\hline 1985 & $5900 / 6500$ & $47 / 52$ & $37000 / 38000$ & $296 / 304$ \\
\hline 1990 & $11000 / 14000$ & $88 / 112$ & $80000 / 92000$ & $640 / 736$ \\
\hline 1995 & $18000 / 26000$ & $144 / 208$ & $155000 / 195000$ & $1240 / 1560$ \\
\hline 2000 & $27000 / 48000$ & $216 / 384$ & $273000 / 388000$ & $2184 / 3104$ \\
\hline
\end{tabular}


considerations should anticipate that once reprocessing plants for thermal into breeder fuel are established and operating, there may be economic incentives to operate these facilities near full capacity. Therefore, fresh fabricated breeder reactor fuel assemblies may also need to be stored.

Depending on the growth demand for the deployment of the breeders, the breeder spent fuel may be planned as feed material for the LMFBR system. The breeder net gain, probably in the forn of bisiket asscmblies, would then be stored or become feed for the LWR system for an interim period. 
III. IAEA SAFEGUARDS

IAEA safeguards are applied elther to all the peaceful nuclear materials in states that are members to the nuclear non-proliferation treaty (NPT) or to the materials and equipment in individual facilities offered to the IAEA by states that are not signatories. In the former case, the IAEA rights and limitations are described in IAEA document, INFCIRC/153: 11 in the latter, the responsibilities are described in INFCIRC/66.12 Although the deta1ls of agreements are somewhat different in the two cases, the general objectives and procedures are similar. In the following, the objectives and procedures for the NPT case are discussed.

A. Objectives and Goals

The general form of an agreement between a State and the IAEA, ard the general nature of IAEA safeguards, are stated in the following paragraphs of INFCIRC/153:

Objective of Safeguards

a. The Agreement should provide that the objective of safeg:ards is the timely detection of diversion of significant quantities of nuclear material from peaceful nuclear activities to the manufacture of .uclear weapons or of other nuclear explosive devices or for purposes unknown, and ieterrence of such diversion by the risk of early detection.

b. To this end the Agreement should provide for the use of materlal accountancy as a safeguards measure of fundamental importance, with contalnment and surveillance as important complementary measures.

c. The Agreement should provide that the technical conclusion of the Agency's verification activities shall be a statenent, in respect of each materlal balance area, of the amount of material unaccounted for over a specific period, giving the limits of accuracy of the amounts stated.

National System of Accounting for and Control of Nuclear Material

a. The Agreement should provide that the Agency, in carrying out Its verification activtties, shall make full use of the State's system of accounting for and control of all nuclear material subject to safeguards under the Agreement, and shall avold unnecessary duplication of the States's accounting and control activities.

The IAEA Safeguards Technical Manual 13, Part A. outlines the objectives, discusses possible diversion paths of nuclear materials, describes the present IAEA safeguards system, and the guidelines for the State's gystem of material accounting and control (SSAC), in order 't:at the IAEA should be able to achleve its objectives. 
Within the IAEA there is general agreement on the meaning of "significant quantites" as related to existing IAEA safeguards practices that involve periodic inventory verification and complementary containment/surveillance of nuclear materia1. The current IAEA goals ${ }^{14,15}$ for quantities of safeguards significance are contained in Table VI.

The IAEA attenres to identify a timeliness of detection of diversion (to be of the same order of magnitude as conversion time) before the material is processed for component fabrication. This time is a function of the physical and chemical form of the material . The current IAEA proposed guidelines14,15 for conversion timeliness are given in Table VII.

\section{B. Basic Assumptions in IAEA Safeguards}

The basic function of the IAEA is the independent inventory verification of the flow of nuclear materials. Therefore, a need for high assurance through physical-inventory verification is assumed.

iAEA inspection activities are assumed basic to an international safeguards system. This not only follows directly from the need for independent inventory verifivation, but also from the number of activities to be performed by an inspector. These may include safeguards equipment maintenance, verification of tamper-indicating features, obser'ation of abnormal operations, nuclear materials shipment and receipt, and multoring of unusual activities, such as the movement of very large equipment $1 \mathrm{n}$ and out of an a rea with nuclear materials. Several desirable benefits may also accrue by virtue of on-site inspection activities. The se include improved timeliness of detection, assessment of the cause of alarms, survelllance for unauthorized activity, and independent inventory verification by means of analytical chemistry assay.

An acceptable international safeguards system must have the clearly demonstrable capability of satisfying a number of basic functional requirements and conditions. Those assumed to be most.important include:

1. High confidence in detecting diversion,

2. Timely detection of diversion,

3. Low fal se-alarm rate,

4. Minimum interference with facility operations,

5. Acceptable cost, and

6. High reliability and/or malntalnability.

C. Current IAEA Safeguards

IAEA safeguards inspections for LWR's now rely on routine reporting by the state and periodic inspection by IAEA personnel. 15 The procedures and the frequency and levels of inspection are negotiated with the state and are documented in accord with the basic document 8,1 . INFCIRC/153, and 2. Facility Attachments. Site specific information and agreements a re included in the Facility Attachments and the Design Information Questionnaire (DIQ) documents. Generally, the state provides routine monthly reports. Periodic inspection by the IAEA occurs from monthly to annually, depending on the type of facility inspected. The negotiated inspection level and frequency a re planned in terms of inspector days per year per facility, with IAEA having 
TABLE VI. Quantitles of Safeguards Significance

\begin{tabular}{|c|c|c|c|}
\hline & Materlal & $\begin{array}{l}\text { Wuantity of } \\
\text { Safeguards } \\
\text { Signif } 1 \text { cance } \\
\text { (SU) }\end{array}$ & S() applies to: \\
\hline \multirow{4}{*}{ 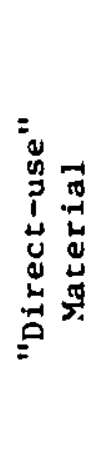 } & $P u$ & $8 \mathrm{~kg}$ & Total Element \\
\hline & $233 \mathrm{U}$ & $8 \mathrm{~kg}$ & Total isotope \\
\hline & $U(235 U, 20 \%)$ & $25 \mathrm{~kg}$ & 2350 \\
\hline & $P u+U\left[\left({ }^{233} u+235 u\right)>20 \%\right]$ & $8 \mathrm{~kg}$ & $P_{u}+\left\langle 33 u+\frac{8}{25}<35 u\right.$ \\
\hline \multirow{3}{*}{ 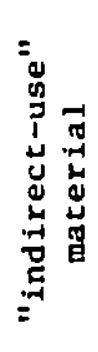 } & $u(235 u<20 \%)^{a}$ & $75 \mathrm{~kg}$ & $235 \mathrm{U}$ \\
\hline & $4 u+u[(233 u+235 u)<20 \%]$ & $8 \mathbf{~ k g}$ & $\mathrm{Pu}+\frac{1}{3} \angle 33 u+\frac{8}{25} \angle 34 u$ \\
\hline & $\mathrm{Ti}$ & $20 t$ & Total element \\
\hline
\end{tabular}

ancluding natural and depleted uranium. 
TABLF. VIl. Guldelines for Estimated Material Conversion Tiwes

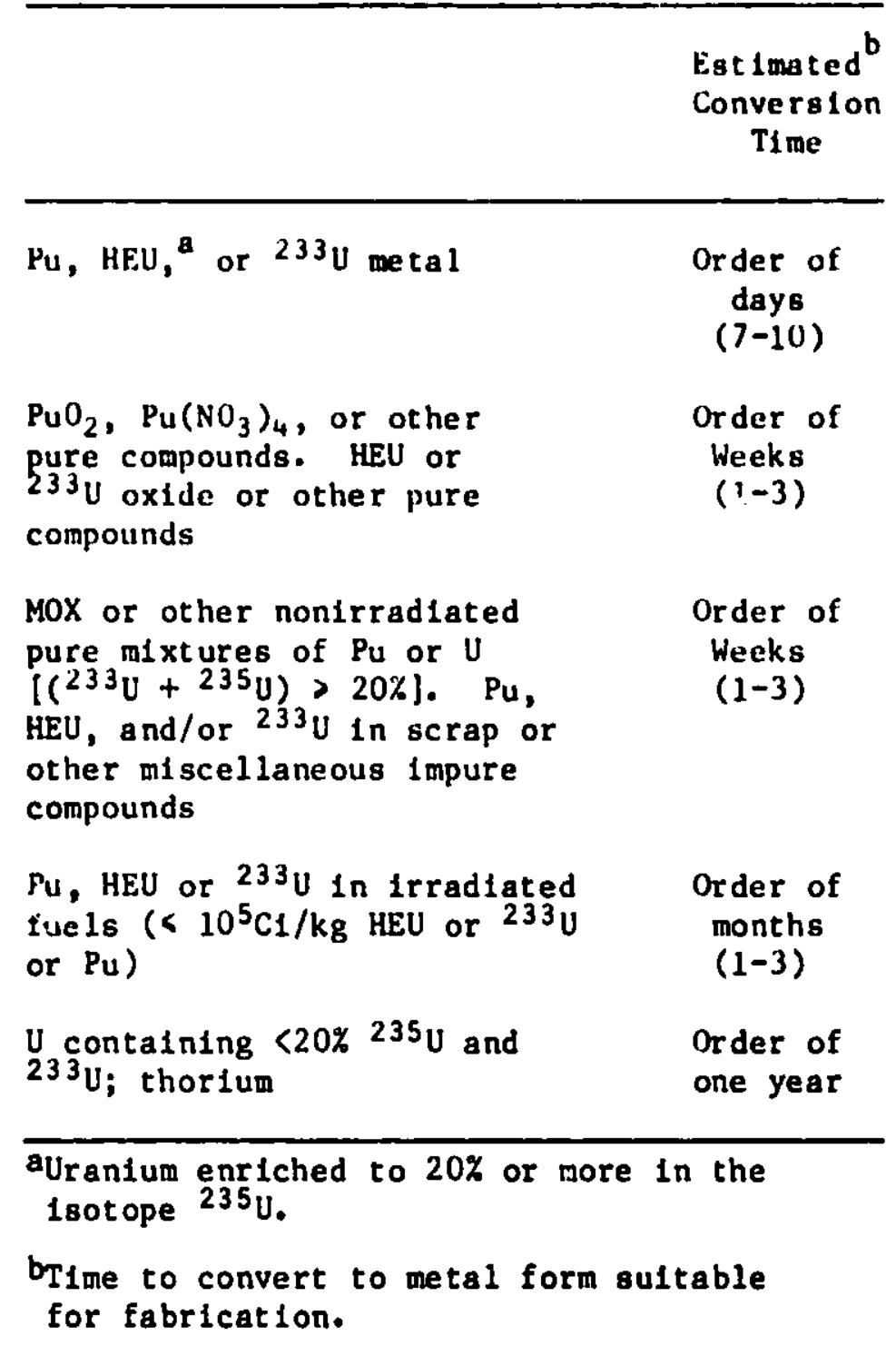


some discretion in the allocation of the effort. The continulty of survelllance is partially provided in some stages of the fuel cycle, e.g. f resh and spent fuel storage, hy supplementing the procedure with a camera survelllance system.

There are two important facts about current IAEA safeguards. First, the times at which statements are made concerning the status of material Inventory (safeguards decision points) occur periodically and of ten are months apart. Therefore, the timeliness goals stated may be difficult to achieve. Second, the routine report from the state is not of value in the timely detection of an inbalance in the flow of nuclear materials if the state 1 self Is 1 nvolved.

\section{Advanced IAEA Safeguards}

The ddvanced IAEA safeguards system approach which may be used as a basis for the options considered in this study, involve continuous or near-real-time survelllance system. Continuous survelllai, :e systems bridge the time between the safeguards decision points now associated with periodic 1nspections. This monitoring may be accomplished by inspector surveillance, by inst rumentation, by routine inventory, or by a combination of the se methods. Unreported actions are sensed by the monitors and cause an alarm to be generated and transmitted to the IAEA. Response to an alam $1 \mathrm{~s}$ a special independent inventory verification procedure which assesses the alarm and includes a sampling of the inventory. Th1s sequence provides the information necessary to reach a safeguards decision. The "timeliness" factor in this approach is the interval from the indication of: a possible unauthorized action to the safeguards decision point at the end of the speclal inventory verification. The times between unauthorized action, alarm, receipt of alarm, and the initiating of the special inventory are system variables that depend upon inspection procedures, communication, and safeguards instrumentation technique 8 and methods.

The possible total safeguards system approach, since it depends upon Inventory procedures that may disrupt normal facility operations, should have a very low frequency of false alarm to be acceptable to the tacility operator. Cooperation by the operator in following procedures to minimize false alarms can and should be encouraged by the safeguards system. The approach pursued is to establish agreed upon administ rat ive procedures which are monitored by the safeguards system. A sensor trip and a deliberate facillty exit, a procedural violation, or a discrepancy in routine inventory can cause an alarm. If assessed as a valid alarm by the inspector, a special Inventory verification 18 performed and a subsequent statement concerning the situation 18 made. The level of this inspection effort depends upon the circumstances, e.8., the number of alams, the type of violations detected, or the amount of elapsed t1me.

In general, the confidence of verification of nuclear materials flows by means of a special inventory will be a function of the time avallable for the special inventory and the amount of material imbalance. For a given inspection procedure and time, a cont 1 nuum of statement 8 can be made concerning confidence of detection and amount of material imbalaice. The results of the same inventory verification could be represented as low confidence in detecting the imbalance of sall quantities of material or high confidence in detecting 
the Imbalance of large quantities of material. Therefore, a system that is adequate to detect an abrupt change in inventory of large quantities of material may have limited capability for timely detection durins a protracted inventory 1mbalance of smill quantitles of nuclear materials.

The introduction of cont Inuous or near-real-time accountabllity and survelllance techniques (Including possibly on-site, full-time IAEA inspectors as an Integral part of the total IAEA safeguards systems) would have the equivalent effect of increasing the time avallable for the special Inventory and in effect would give a high confidence of muclear material tlow verification, even for the flow Imbalence of small quantities of nuclear material s. 
IV. METHODS FOR ACHIEVING IAEA SAFEGUARDS

A. Transition Period

A.1 LWR Spent Fuel in Storage and Reprocessing for FBR Use: The nearterm safeguards concerns for phasing the FBR power systems into the existing deployed LWR power fuel cycle systems will be directed primarily to the characteristics of the transition period where the major fuel-cycle facilities such as 1sotopic enrichment facilities and reprocessing facilities are operating at economies of scale consistent with the LWR power options.

In the early phase of FBR deployment, the FBR's would be started and sustained with plutonium produced by the thermal reactors. The FBR spent fuel would be stored un. 11 the excess supplies of thermal-reactor spent fuel had been drawn upou and the breeder reprocessing.

During the interim period, breeder operation would alter the manner in which the total quantitles of spent fuel are placed in storage. The quantity of spent fuel at dispersed sites that would need to be safeguarded would be reduced.

In Fig. 5 are typical annual mass flow requirements and spentfuel output for the reference LWR (U.S.-Indian Point -900 MWe).17 Referring to the reference FBR fuel mass flow, Fig. L, the FBR would absorb the annual spent-fuel production of about 14 LWR's in addition to a two-year backlog. If the LWR spent fuel 18 stored at the reactor, about 400 tonnes of spent fuel per year $1 \mathrm{~s}$ added to the storage at about 14 sites. If the spent fuel $1 \mathrm{~s}$ reprocessed to fuel an FBR, the equivalent quantity of contained plutonium is stored in the FBR spent fuel at a single FBR site at a rate of about 31 tonnes per year (core and blanket assemblies containing $2758 \mathrm{~kg}$ of plutonium). In addition, about 650 tonnes of spent LWR fuel containing about 6 tonnes of plutonium is committed to the fuel cycle as the FBR core inventory.

The safeguards consideration in this transition period will involve mainly the LWR fuel cycle oystems facilities such as 1sotopic enrichment plants, reprocessing and fabrication facllities, transportation, and storage of spent fuel.

The statistical sampling methods for item (spent core and blanket assemblies) Identification and accountability, should form the basis for storage design and management to enhance the effectiveness of survelllance and the contalnment techniques. The safeguarding of spent fuel 18 based on Item accountability, and the number of fuel elements as well as the dispersed locations add to the demand of sefeguards resources. Table VIII shows the number of elements and locations that would be provided by each FBR if fueled with plutonium recovered from LWR or HWR spent fuel.

The introduction of plutonfum-containing fuel into the fuel cycle systems introduces a more direct visible profile of the disposition of plutonium. Th1s greater visibility results rot only from the application of effective continuous IAEA containment and survelilance methods, but also from the direct applicabllity of material accountancy by chemical analytical assays (destructive assay) and nondestructive NDA assay. 
ANNUAL FUEL MASS FLOW DIAGRAMS FOR REFERENCE PWR REACTOR

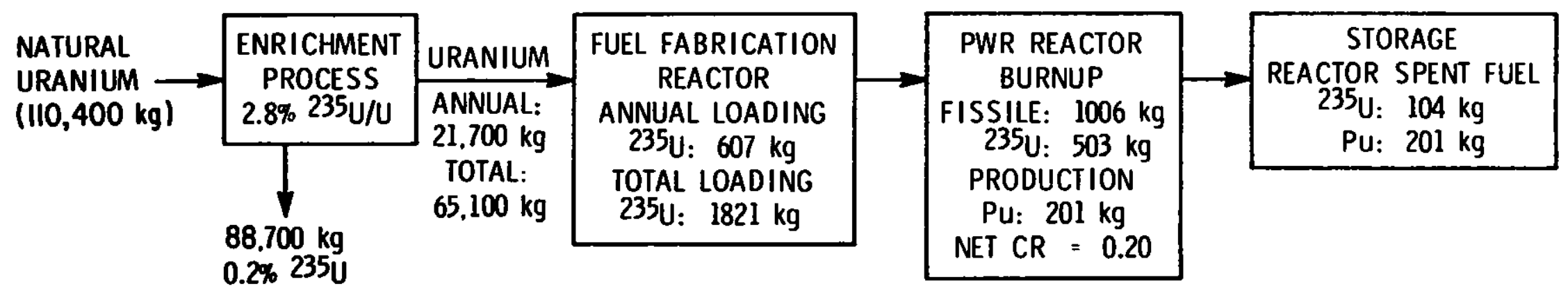

F1g. 5. Diagram of Annual Fuel Mass Flow for the Reference PWR. 
TABIE VIII. Relative Magnitudes of Spent-Fue 1 Iten-Accountability Tasks for Equivalent Quantities of Contained Plutonium

\begin{tabular}{lcc}
\hline & $\begin{array}{l}\text { Number of } \\
\text { Elements } \\
\text { Per Year }\end{array}$ & $\begin{array}{c}\text { Number of } \\
\text { Sites }\end{array}$ \\
\hline LWK & 820 & $14^{\mathrm{b}}$ \\
IWR & 3174 & $8^{\mathrm{b}}$ \\
FHK & 206 & $1^{\mathrm{c}}$ \\
\hline
\end{tabular}

Notes:

aFBR spent fuel does not appear unt 11 about $3-1 / 2$ years after LWR or liWk $f$ ue 1 is removed from item accountability.

Wominal sites of 1 GWe each.

cSuper Phenix equivalent ( 1.2 GWe) 
Safeguards at a storage site will use a combination of instrumentation at the site, closed circult $T . V$. monitoring, fuel assembly integrity devices, physical inspection by various personnel, and a varlety of physical protection mechanisms. Review by inspectors can vary from perlodic to residency and can be supplemented by the transmission on a real-time basis of a tamper-indicating communication of data from selected safeguards sensors.

Referring to a posstble reference IAEA Safeguards System (Figs. 6 and 7, some sensors (under development at Sandia Laboratorles ${ }^{y}$ ) that may be considered for monitoring spent fuel assemblies in storage and handing are radiation monitors, crane monitors, pool acoustic monitors, portal monltors, and fuel assembly identification devices (FAID).

Radiation Monitors: Typical LWR spent fuel assemblies have a radiation source of approximately $10^{5} \mathrm{Ci}$. A shipping cask will not entirely shield this source, resulting in a radiation field of about $5 \mathrm{mR} / \mathrm{hr}$ at about 3 meters from a shipping cask. Therefore, a shipping cask containing spent fuel is readily detectable even in comparable background areas. The average radiation level during a time interval is measured and the information is made avallable to a computer system by tamper-indicating dilti links.

Crane Monitors: The crane monitor system will provide information concerning crane activity at spent fuel storage facllities. The crane sensor system concept uses strain gauges located in pairs along the crane bridge ralls. The pairing establishes the direction of travel as the crane passes the monitor point. The load on the crane can be determined as it passes over the sections of track that have been instrumented with the strain gauges. All components, except the gauges, will be placed in tamper - Ind1cating sensor modules. Voltage and current monitors will indicate tampering with the gauges. The data from the monitor are made avallable to a datacollection module through tamper-indicating data links.

Pool Acoustic Monftors: The pool acoustic monitor (PAM) w1ll monitor underwater acoustic activity within the storage pool. The primary objective of the PAM will be to provide an intrusion alert output whenever acoustic signals within the pool are characteristic of fuel assembly handing, particularly those activities associated with removal of nuclear fuel from storage locations to elther the reprocessing portion of the plant or the cask loading pool.

Portal Monitors: Monftors to control the movement of nuclear materials through access portals, employ radiation detectors to detect the spontaneous emlssion of gamma-rays or neut rons.

Fuel Assembly Identification Device (FAID): The FAID system provides unique identification and integrity information for independent verification of each ruel assembly in the inventory. The concept being puraued is to place an ultrasonic FAID on each fuel assembly that can be interrogated with an ultrasonic scanner. The data from this sensor will be collected by a data-collection module through tamper-indicating data links. 


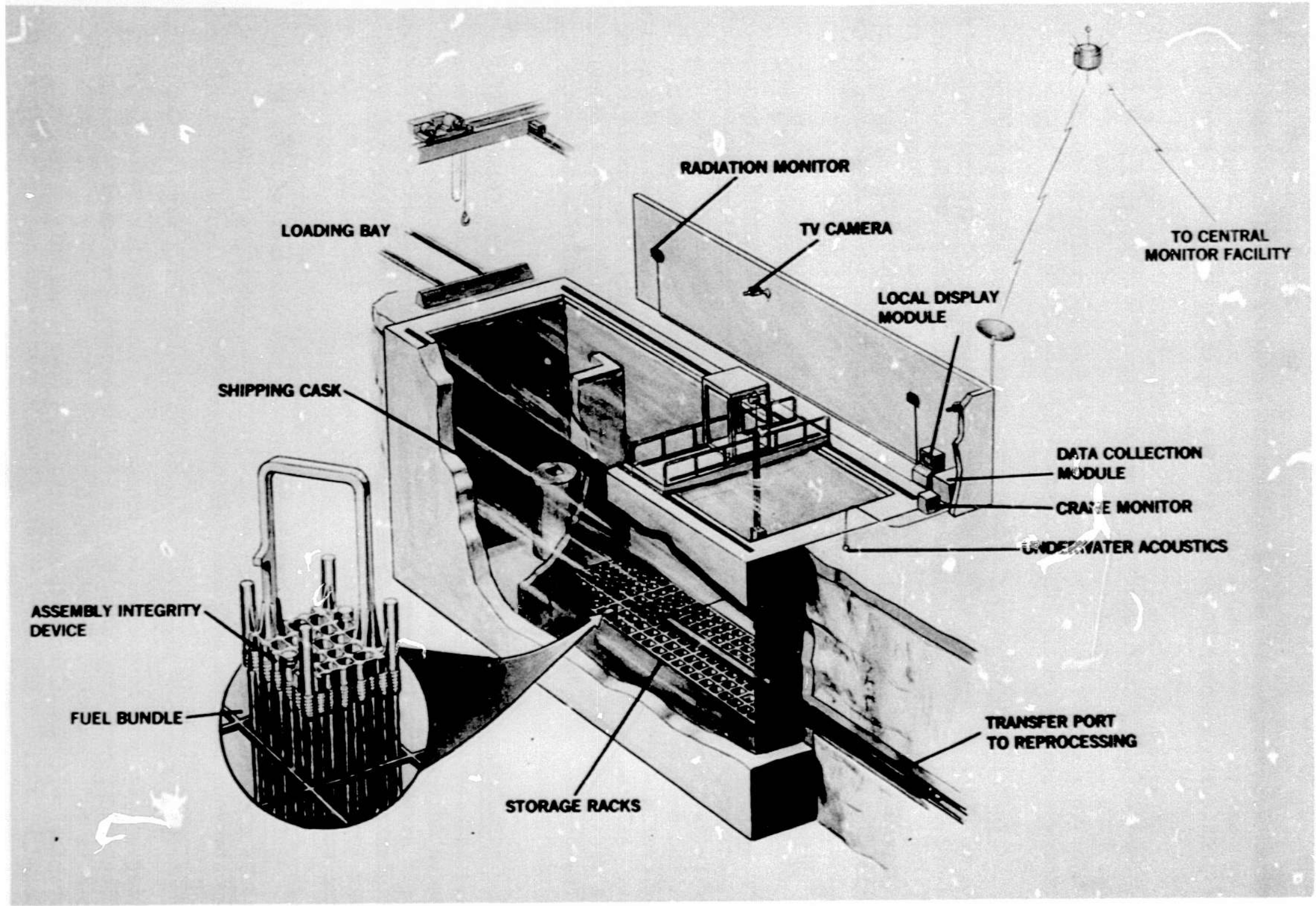

Fig. 6. Unirradiated and Irradiated Fuel Storage Monitoring. (See ref. 34) 
MATYOMAL CONTROL

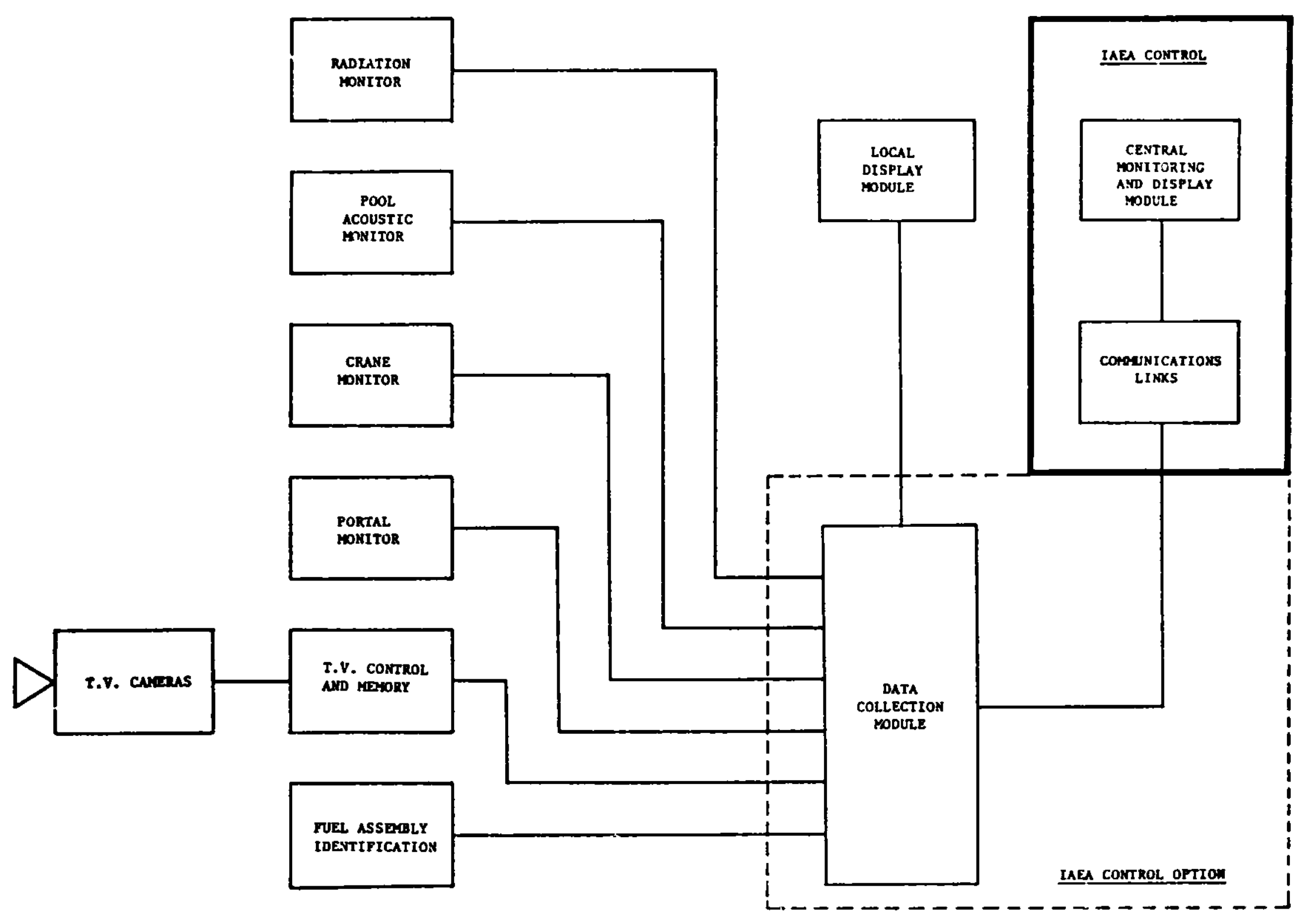

Fig. 7. Facility Data Collection Moduîe Computer System. 


\section{Other Systems for Development}

1. Underwater Optical Viewing 19,

2. Cerenkov-glow Vision Device20,

3. Spent Fuel Scanning for Neutron and Gamma Emission/Burnup,

4. Spent Fuel Temperature Monitoring, and

5. Active Neutron Interrogation NDA Methods.

A. 2 FBR Spent Fuel Reprocessing: The length of the transition period in which only LWR reprocessing operate, will be determined in part by the economics of introducing Fis spent fuel reprocessing systems. In the absence of specific design studies, the economy of scale assoctated with LWR systems ${ }^{6}$ ( 1500 tonne/yr), is usually assumed as applicable for FBR systems. Additional factors such as criticality condittons will influence the design features of the FBR reprocessing plants, and the economy of scale for FBR may be in the capacity range of about 200 tonnes/yr. Figures 8 and 9 respectively, show the material flows through an LWR 1500 tonnes/yr reprocessing factlity and an FBR 200 tonnes/yr core and blanket reprocessing facility.

The 200 tonnes/yr capacity would service 8-10 FBR's. A comparison of the materials flow in the FBR and LWR at the respective capacities indicates that the total throughput of $\mathrm{Pu}$ tur the two systems do not differ greatly. The criticality design constraints on fissile-materlal accumulation and distribution are geometrically safety-related design criteria and as such would be analogous to the LWR reprocessing facllity. As a consequence, the major component and tcchniques of IAEA safeguards systems for the FBR reprocessing are expected to be not too different from those developed for the LWR fuel cycle. In Table IX are 1isted: Key Measuring Points (KMP), related reprocessing stages, and the amount of material necessary to accumulate the significant quantity of approximately $8 \mathrm{~kg}$ of plutonium. The total amount of material for each stage appears to be large enough for detection bv NDA techniques of abrupt changes in material inventory. The frequency of inspection and material balance measurements, and containment-surveillance automated control measures would have to be studied for optimizing the detection of protracted material imbalances.

Future studies on the FBR economy of scale for FBR reprocessing systems may result in capacities higher than the 200 tonnes/yr used in the above 1llustration. In the hjgher capacity systems, the geometrically related criticality-design constraint may indicate a systems layout where more than one parallel flow streams are utilized with each st ream probably having a flow throughput not much h1ghel from that of the 200 tonnes/yr facility. Much of the safeguards systems developed for the closed LWR fuel cycle with some modifications is -xpected to be applicable to the FBR fuel cycle.

A.3 Direct Fissile Material Accountability in Fresh and Spent Fuel Storage: The IAEA safeguards a spect of long-term interim stcrage of $f$ resh and spent fuel, the transfer of ownership of the fuel and the resolutions of sh1pper/recelver talances, may develop the safeguards need for a direct 1dentification of fissile content and a nuclear materlal balance accountability. The safeguards at AFR storage sites, which will involve a combination of sensors and inspection plans, may have :o be supplemented by either Analytical Chemical Assay or by NDA techniques. 


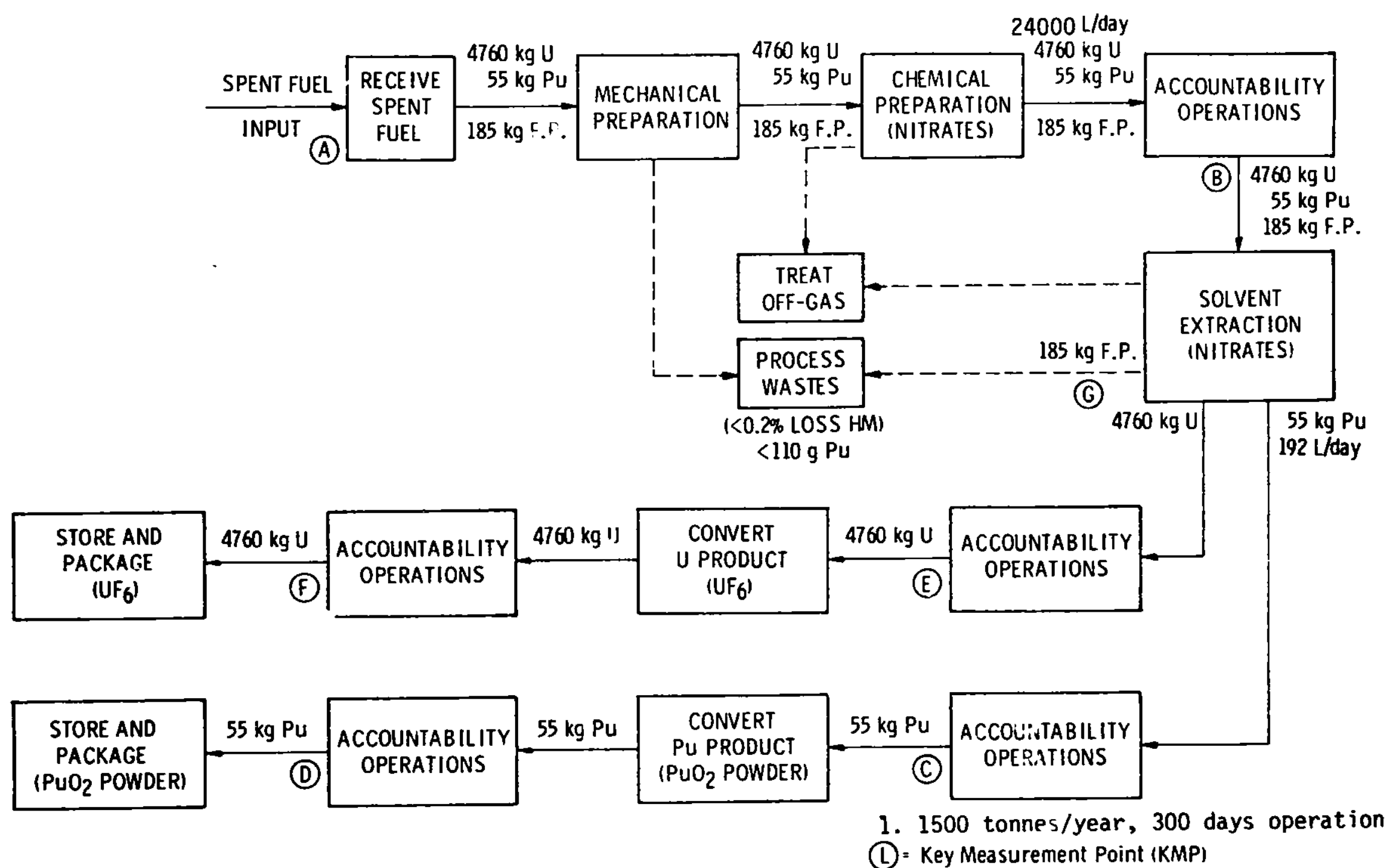

Fig. 8. LWR Reprocessing Flow Diagram (kg/day).1 


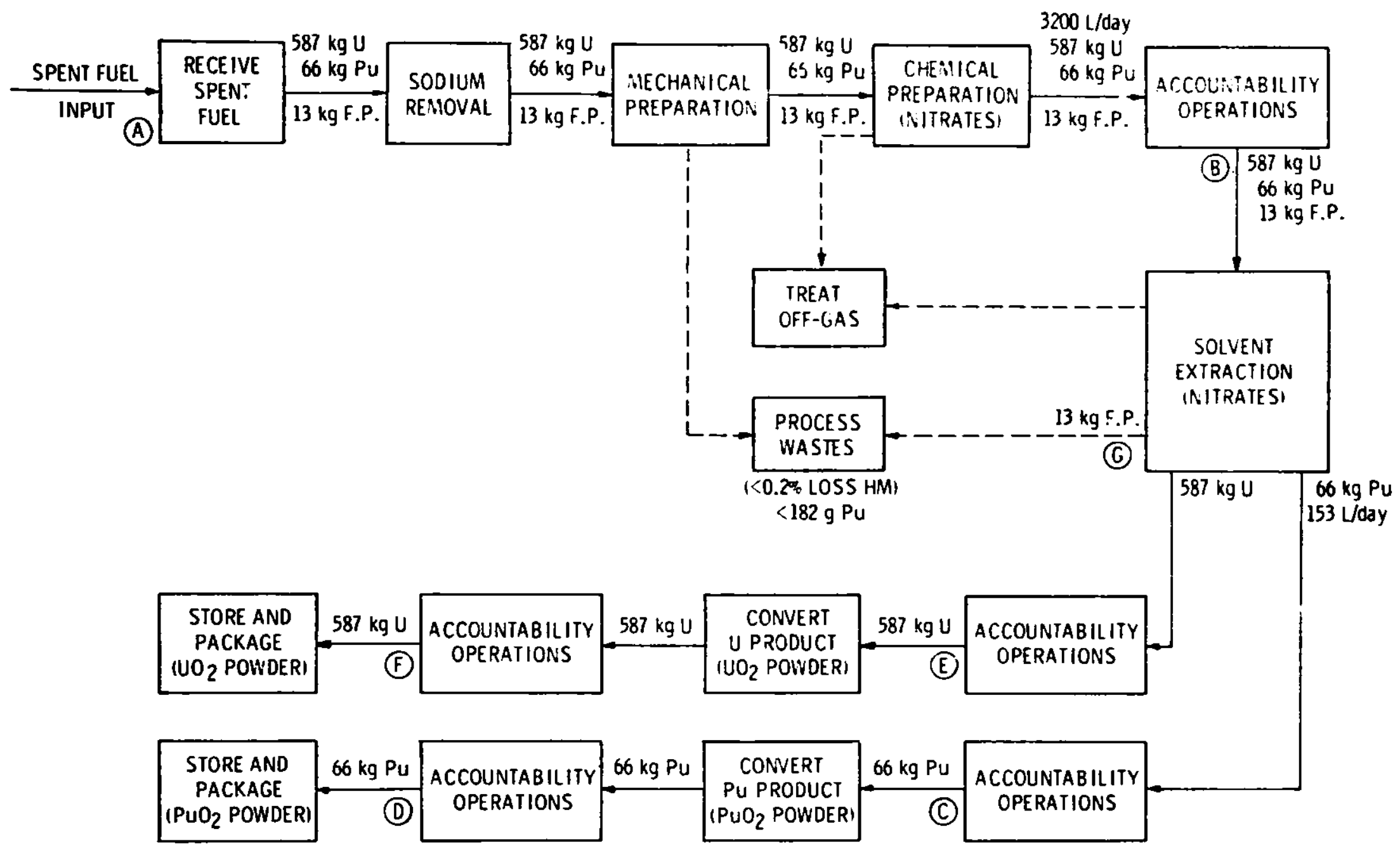

1. 200 tonnes/year, 300 days operation (L) $=$ Key Measurement Point (KMP)

Fig. 9. FBR Core and Blanket Reprocessing Flow Diagram (kg/day). I 
TABLE IX. Key Measurement Points (KMP) Typical Flows and Diversion Possibllities for 200 tonnes/yr FBR Core and Blanket Reprocessing Plant

\begin{tabular}{|c|c|c|c|c|c|}
\hline \multirow[b]{2}{*}{ KMP No. } & \multicolumn{2}{|c|}{ Flow Rates } & \multicolumn{2}{|c|}{ Concentration } & \multirow{2}{*}{$\begin{array}{l}\text { Mass of } \\
\text { Materials kequired } \\
\text { for } 8 \mathrm{~kg} \mathrm{Pu} \\
\mathrm{kg}\end{array}$} \\
\hline & $\mathrm{kg} \mathrm{Pu/day}$ & $\mathrm{kg} \mathrm{U/day}$ & $\mathrm{Pu} \mathrm{g} / \mathrm{L}$ & $11 \mathrm{~g} / \mathrm{L}$ & \\
\hline $\begin{array}{l}\text { A (Irradiated } \\
\text { Fue } 1 \text { ) }\end{array}$ & 60 & 587 & - & - & 81 \\
\hline $\mathrm{B}(\mathrm{U} / \mathrm{Pu}$ Nitrate $)$ & 66 & 587 & 20.6 & 183 & 388 \\
\hline$C$ (Pu Nitrate) & 66 & Neg. & 431 & Neg. & 18.5 \\
\hline $\mathrm{D}\left(\mathrm{PuO}_{2}\right.$ Powder $)$ & 66 & Neg. & - & - & 9 \\
\hline E (U Nitrate) & 66 & 587 & Neg. & - & - \\
\hline $\mathrm{F}\left(\mathrm{UO}_{2}\right.$ Powder $)$ & Neg. & 587 & - & - & - \\
\hline $\begin{array}{l}\text { G ("ligh Level } \\
\text { Liquid Waste) }\end{array}$ & $<0.13$ & $<1.2$ & - & - & - \\
\hline
\end{tabular}


NDA techniques are not currently applicable for direct measurement of flssile content in spent fuel because of the radiation field of fisssion-product gamma-rays. This leaves the classical analytical chemistry systems to account within acceptable accuracy and rea sonable turnaround time, for the disposition of the fissile and fertile materials in siorage. However, active neutron interrogation NDA methods for fissile content measurement in fresh and spent fuel may be developed for this purpose.

A.3.1 Isotopic Safeguards Techniques: For this purpose the combination of isotopic correlation saceguards techniques being developed for IAEA Safeguards at Pacific Northwest Laboratories, 21 Belgium, and Federal Republic of Germany; and the analytical methods of microsample preparation for the simultaneous isotopic analysis of uranium and plutonium may develop into an effective technique.

This safeguards technique is based on the use of $\mathrm{f} r e s h$ and spent fuel data on the plutonlum and uranium isotopic content and ratios, and on related changes occurring as a function of the irradiation history in the power reactor. Sampling of fuels from selected representative fuel element rods as processed in a small scale "laboratory facility", coupled with various analytical methods, may be used to measure the uranium and plutonium concentration and isotopic compositions. Relationships existing between the depletion and production of the isotopes have been established and correlated with reactor design codes, and this forms the basis of the data consistency evaluation between analytical measurement (burnup data) and chemical processing and fabrication plant data. The safeguards techniques have been developed to include, a) verification of plutonium content of irradiated fuels measured at input to a chemical reprocessing plant, b) confirmation of avallable historical Information, c) data consistency evaluations, and d) diagnostic evaluation to define burnup characteristics from the measured data.

A.3.2 Microsample Preparation: The method of isotopic analysis of very small samples of plutonium and uranfum has been developed in the U.S. 22 The method involves the use of anion resins for the separation of both elements and the direct loading of a single resin bead onto a mass spectrometer fllament. In the case of irradiated fuels, the direct separation of plutonium and uranium from fission products and from isobaric interferences from americium and curfum (these elements do not absorb on the anion resin) has the effect of measuring the isotopic abundance and the total quantity of $U$ and Pu. The microsample (micro-to nano-gram sample sizes) technique possesses many advantages which enhance safeguards assessment: a) more representative sampling, b) reduced radiation hazards from smaller samples, c) less shielding and transport cost for sample handling, d) greatly simplifled chemical preparations which eliminate fission products and actinide isobaric interferences, e) direct loading into the mass spectrometer, f)more precisly established minor isotopes, g) reduced time between sampling and measurement analysis.

The preliminary development of this safeguards method indicates that rellable isotopic analysis of plutonium and uranium in $f$ resh and spent FBR reactor fuel can be accomplished with minimal chemistry and sample handing on a very small scale. The international safeguards aspect of this method would int roduce the possibility of sampling the unirradiated fuel rods in storage prior to reactor loading and the irradiated fuel rods in storage prior to reprocessing. The analytical chemistry laboratory for attaining and measuring the aliquot solution can be performed at the reprocessing plant site with IAEA control. 
B. FBR Fuel Cycle Phase

B.1 FBR Power Plant Safeguards: The significant safeguards concerns of the fast breeder reactor $23,24,25$ is the fuel and blanket assembly surveillance and accountability during the sequential period of: unloading the assemblies from the transport casks (current designs include capacitles of 6 to 12 assemblies) into the temporary storage pool, loading the assemblies into the reactor proper, unloading the spent fuel and blanket assemblies from the reactor into the temporary storage pool, and finally the removal of the assemblies from the storage pool and transfer to the shipping cask. The unique feature of this sequence of stages is that the fresh and spent fuel assemblies each containing 12 to $14 \mathrm{~kg}$ plutonfum are almost continuously submerged in a pool of sodium. This limits direct visual inspection and assembly identification to those times when the assembly is being handled in the transfer tubes of the loadingunloading machine, during the sequence of movement through the transfer (handling) cell to the conditioning cells, fad loading into the spent fuel shipping cask. The total time interval fr \& recelving fresh fuel assemblies to shipping of spent fuel and blanket ass ublies may be in the order of several years. The usual methods and techniques which the IAEA applies for safeguarding current commerclal power reactors would involve excessive agency effort in safeguarding LMFBRs and may not always be adequate.

Diversion analysis considerations for the development of 1 tem accountability and contalnment/survelllance instruments, would have to include two different diversion strategles: (a) The abrupt diversion of at least one assembly (or fuel-dumny substitution) within a short time, and (b) The protracted diversion of a significant quantity of nuclear materlal by removal of some fuel elements within the assemblies (by pretense of examination for experimental need or by dismantling of falled fuel assemblies) over an extended period of time. The diversion considerations would therefore include nuclear material 1tems which may be diverted within the limits of verification capability and/or exceeding present verification capability.

The diversion analysis approach would involve the selection of MBAs and KMPs to cover: (a) nuclear material flow verffication of unirradiated assembly receipts, intact and non-intact irradiated assembly flow disposition, and storage; and (b) physical inventory of unirradlated and irradiated assembly storage areas such as recelving vessels, buffer storage tanks, preparation or conditioning cells, sodium and non-sodium cooling storage vessels. To maintain continuous knowledge of the flow and inventory of assemblies, appropriate and avallable containment/surveillance measures would necessarily be used to supplement the 1tem accountability measures at MPs.

B.1.1 Item Accountabllity: The basic unit of one fuel assembly and one blanket assembly may be assumed applicable for 1tem accountability in the normal operating mode of LMFBRs. However, in the current and near-term development stages of LMFBRs, there may exist experimental assemblles which may be dismantled such as in the U.K. PFR system, there may be a need for dismantling a normal assembly for experimental reasons, or there may be fuel assembly fallures which require dismantling, speclal handling and/or storage. The inventory and flow verification of these assemblies as well as the intact assemblies should be examined with respect to the plant layout design features, operating modes, and handling programs. 
Identification marks of the fabricator, and other possible identification signatures with properties of having a unique one-to-one correspondence with the fuel assembly, may be identified and examined for applicability by IAEA to unirradiated and 1rradiated assemblies in specific reactor plant design and fuel handling systems. Considerations would have to include methods to maintain the integrity of the rod-element configuration within the assembly.

To establish an 1tem accountability system, the design of the loading/ unloading machine, and the transfer-conditioning cells will be examined for design features to allow accommodating direct visual and physical Identification techniques for contalnment/survelllance and accountability purposes. The adaptability of measurement equipment and/or inspection methods may be influenced by the facility constraints. The implementation of the measurement systems available to the Agency and the Inspection methods may therefore require some modification for unique applications.

Several assembly-accountabllity sensor techniques for undersodium viewing in loading and unloading and storage of fresh and spent fuel are:

B.1.1.1 Ultrasonic: Under Sodium Viewing Systems 26: The Inspection technique basically uses ultrasonic techniques to provide both lmaging and ranging capability. For lmaging applications, focused 5-MHz transducers scan the region of the core and blanket with a high degree of resolution (0.150-inch-diameter holes) while operating under 5 meters of liquid sodium. With 2-MHz transducers, ranging scans can accurately measure distances up to 5 meters. The system, although developed for location and positioning of assemblies in the reactor may be used for safeguards purposes to determine the identity of the assemblies, the respective loading positions, and the orientations of the assemblies by forming 1mages of coded notches or Indentations. An ultrasonic technique has been developed by Euratom to provide signatures of fuel assemblies using metallic identification. The fur ther development of these techniques with design features emphasizing the safeguards aspect of accountability in the IAEA program of inspection 18 necessary. The current development status of the under-sodium viewing systew is represented in $\mathrm{Fig}$. 10.

B.1.1.2 Mechanical: Under-Sodium Reader: This concept, while untested and unsophisticated, would consist of a single cylindrical unit similar to a grappling device with a properly designed needle-roller or fine indicating feeler juxtaposed next to sealed contactors. The device would be designed to fit over the top end of a fuel assembly. If the top of the fuel assembly is encoded with a serles of ralsed or indented markings, the spring loaded needle could cause the contactors to open or complete a circult as the cylindrical unit is rotated about 1 ts vertical axis. This technique would require some intitial design studies to examine the feasibility of the method. This method would require standardization of the design of fuel assemblies and the adoption of an international code for identification.

B.1.1.3 A Mult1layer Fully Encapsulated Self-Powere! Direction Gamma Monitor for Use in Spent Fuel Storage Fac1lities: When a metal-dielectric-metal multilayer atructure 18 placed in a gamma radiation field the electrical response obtained is atrongly dependent on the geometry, the applied fields, the external circultry, and the past history of the geometrical influence on the measured response. A metal-dielectric multilayer 


\section{UNDER-SODIUM VIEWING SYSTEM FOR FFTF/LMFBR}

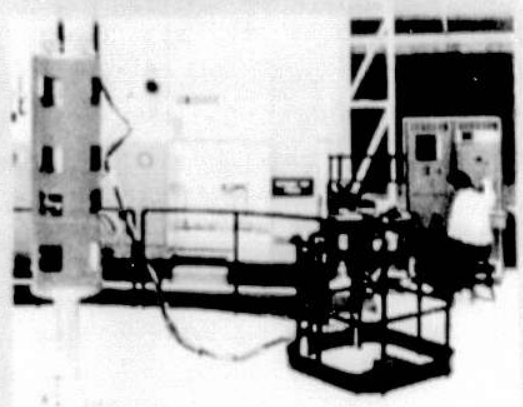

A. USV SYSTEM OPERATING IN CRCTA

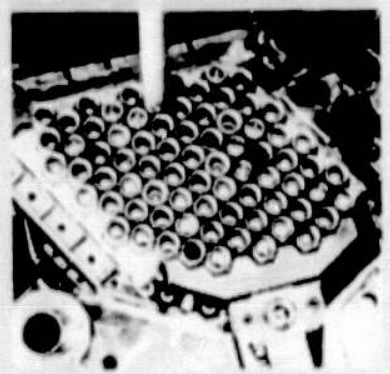

C. CRCTA CORE PRIOR TO FILL WITH 16 FEET OF SODIUM

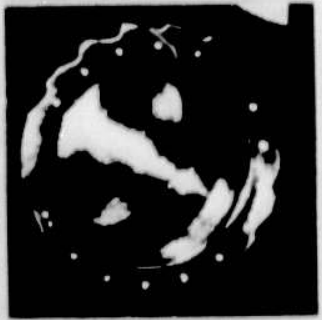

E. TOP OF ONE CORE SUBASSEMBLY

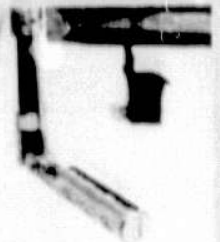

B. SCANNER

CARRIES 34 SPECIAL

ULTRASONIC TRANSDUCERS

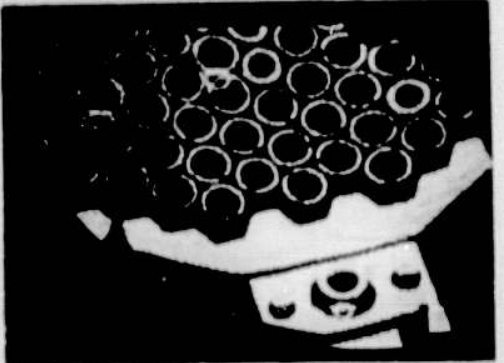

D. USV IMAGE OF C.

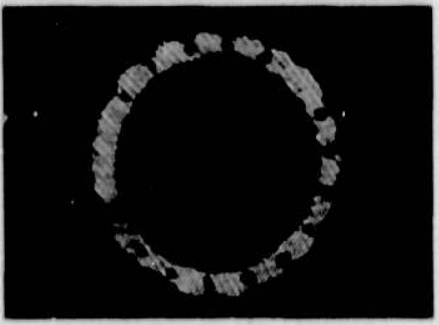

F. IMAGE OF E. WITHOUT ENHANCEMENT

POTENTLAL. APPLICATIONS:

- CORE SUBASSEMBLY LOCATION AND IDENTIFICATION

- PRECISE LOCATION OF IN-VESSEL COMPONENTS: IVHM, CLIRA, INSTRUMENT TREE, LLFM

- PERIODIC INSPECTION OF CRITICAL COMPONENTS THERMAL BAFFLES, WELDS

- SEARCH AND RETRIEVAL GUIDANCE INFORMATION FOR MISPLACED OR FOREIGN OBJECTS

Fig. 10. Under-Sodium Viewing System for FFTF/LMFBR.

(See ref, 26) 
arrangement can be found that exhibits directional discrimination. A detector of this type has been constructed and tested in the Argonne Thermal Source Reactor (ATSR).27 The detector has the advantage of requiring minimum maintenance, making it 1deal for long-term deployment (e.g., in sealed fuel storage pools). Sensitivity of the detector and its size make 1t possible to construct an array of these detectors to provide a detalled signature of the fuel is a localized region of the storage pool. The detector array, when operated in a continuous mode, could be used to detect the movement of fuel, particularly the motion along a line in a plane that included the axis of the array of detectors. In the case of irradiated fuel assemblies, a multilayer fully encapsulated monitor of this type will require some testing in an intense gamma/neutron environment to examine the effects of long term irradiation on its response. In addition to radiation damage studies, numerical simulations would be required to establish the optimum thicknesses of the dielectric and proper cholce of materials.

B.1.2 Contalnment/Survellance: In the reactor power plant phase of the FBR fuel cycle, the 1tem-accountability sensors would be complemented by a combination of instruments at the site such as closed-circuit T.V. monitoring, fuel assembly integrity devices, physical inspections by varlous personnel, and a varlety of physical protection mechanisms. Review by inspectors can vary from perlodic to residency and can be further supplemented by the transmission, on a near-real-time basis over tamper-indicating communication of data from selected safeguards instrumentation. The sensors primarily applicable in this phase of the cycle are radiation monitoring devices, crane movement monitors, acoustic detectors for fuel movement under sodium, portal monitors, metal detectors and access control for equipment.

\section{B.1.3 IAEA Inspection: The development of the inspection ef fort} would have to include optimizing surveillance inspection activities, review of data acquisition by sensoring instruments, and review of power plant operation records, if avallable, to independently verify the material inventories. The inspection plan would include consideretions such as: equipment maintenance, verification of tamper-indicating features of data acquisition systems, review and evaluation of dats relating to reactor power operations, fuel loading schedules, verification of unit assembly flows and storage dispositions, identification of operating anomalies, nuclear materials shipment and receipts, and data relating to movement of operating equipment in the fuel handling system, (Including the indexing pattern of the non-concentric rotating plug systems). The inspection activities and frequency of inspection determined for each strategic point would be optimized consistent with the guldelines of INFCIRC/153 and within the limited resources of the Agency.

The fuel and blanket assembly scheduling plans in- and out of- reactor should be reviewed for the plant and maintained as an integral part of IAEA inspection data base. Record keeplng systems of reactor operations and fueling schedules, as developed by the State System of Accounting and Control (SSAC) and assumed available to the Agency, are to be studied. Th1s Informetion would be used as a guide in determining inspector access to the systems, frequency of Inspection, and the specific type of Inspection activity.

To optimize the limited resources of the Agency, the poss1bility of applying and ut1lizing tamper-indicating data link and data collection modules, elther independently or in a verification mode with the SSAC system, should be an important consideration. 
B.1.4 NDA Techniques: The current NDA techniques for 1 tem accountability can only distinguish between different classes of assemblies, $1 . e$. , fuel, blanket and/or dummy replacement. There 18 no distinction made between the individual assemblies. It is not apparent how effective NDA techniques may be if this information is not supplemented by subsequent confirmstory information that a replacement has occurred.

The safeguards instrumentation for the identification of unirradiated and 1rradiated assemblles will probably include the gamma-ray survey Instruments: SAM-2 or BSAM, Ge Detector, and G-M counter arrays. The passive and active neutron counters which are currently avallable are the slab detector ( $\mathrm{BF}_{3}$ counter), and the neutron collar $\left({ }^{24 l} \mathrm{Am}-\mathrm{LI}\right.$ neutron source) and would allow a level of identification between classes or types of assemblies 1.e. unirradlated or irradlated, fuel or blanket, dummy subst1tution and/or fuel-blanket interchange. The safeguards effectiveness for some of these instruments is compromised by the self-shielding effect of the heavy-metal and sodium contained in an LMFBR assembly. The effectiveness of the system may therefore have to be evaluated in terms of a combination of sensor measurements performed in a simultaneous mode. The simultaneous reading of the fabricators identification markings, the tamper-indicating signals, and the isotopicradiation measurements, may prove to be an applicable and an effective measure of introducing assembly flow verification. An added level of consistency in flow verification may be effected if the difference in isotopic-radiation measurements reflect the irradiation history of a specific assembly.

The utilization of overlaying several safeguards techniques for a consistency mode of assembly flow verification within the current resource limftations of the Agency should be considered.

B.2 Reprocessing and Conversion: The safeguards concerns with respect to the reprocessing and conversion phase of the FBR fuel cycle will be based, if applicable, on modifications and adaptations of those safeguards techniques and systems being developed and planned (see Ref. 28 and 29) for use in the LWR spent-fuel reprocessing and conversion facilities and for LWR isotopic enrichment facilities. The design of assay and accountability systems is directed toward providing a system to establish material accountability information on a near-real-time basis. The system is to be designed to determine fissile content of batches of material in process throughout the plant by measuring representative samples coupled with the ability to maintain continuous contalnment and survelllance of the material flow through the various reprocessing and conversion stages.

The system of material accountancy, contalnment and survelllance described in the introductory sections is applicable to the reprocessing and conversion phase of the FBR cycle. There are no unique processing requirementis for the FBR-related stages including total plutonium throughput. Consequently, the safeguards systems for the LWR plants are directly applicable to the FBR fuel cycle. However, th1s report will attempt to scope the safeguards options or combination of options that can be designed for the FBR safeguards system using the various sensor systems currently avallable and/or in the developmental stage. 
B.2.1 Material Accountancy: In general, conventional contemporary safeguards systems are based on discrete-1tem counting and material-balance accounting after perlodic shutdown, cleanout, and physical inventory. The typical materlals balance generally encompasses the entire facility or a major portion of the process and is formed by adding all measured recepts to the inftlal measured inventory and subtracting all measured removals from the final measured 1nventory. During routine production, materials control is primarily vested in administrative and process controls, augmented by secure storage for discrete items, sealed containers, etc.

Although conventional methods of material-balance accounting Involving shutdown and inventory are essential for effective control of nuclear materials, there exist inherent limitations in both sensitivity and timelinesis. Sensitivity is limited by measurement uncertainties that might obscure the diversion of significant quantities of nuclear materials from a large-throughput plant, timeliness by practical difficulties, economics, and the resulting infrequency of process shutdown, cleanout, and physical inventory.

The development of nondestructive assay (NDA) technology, stateof-the-art conventional measurement methods, and special in-plant sensors, when combined with supportive computer and data-base management technology have provided the technical basis for improved alternative methods for safeguarding nuclear facilities. Greater sensitivity and timeliness in nuclear material control can be achieved by dividing a nuclear facility into descrete accounting sections, materlal balance areas (MBA), or unft processes, around which individual balances can be drawn, using measurement techniques capable of producing assay results in near-real-time.

A unft process can be one or more chemical or physical processes. It is chosen on the basis of process $\log 1 \mathrm{c}$, the residence time of material within the unit process, and the ability to perform rapid quantitative measurements and to draw a near-real-time materlals balance. By partitioning a facility into unft processes and measuring all materlal flows across unitprocess boundaries, the location and movement of nuclear material throughout the plant can be localized in both time and space independent of the inventory schedule. Material balances circumscribing such unit processes are called "dynamic" material balances to distinguish them from conventional balances drawn after a shutdown, cleanout, and physical inventory.

B.2.1.1 Nondestructive Assay: The requirement for prompt detection of diversion or losses involving small quantities of material has led to the development and eventual implementation, on commercial-scale facilities, of automated systems for near-real-time measurements and control of flssile materials. The timely, in-line measurements available through nondestructive assay provide the basis for near-real-time materials control. Depending on the types of materlals that pass the varous measurement points, optimal NDA sensor instrumentation can be adapted from existing designs for in-line operation. The U.S.28,29 has been developing a number of NDA systems for use in plutonium facilities. Several NDA methods have been developed for analysis of nuclear materials at various stages in the nuclear fuel cycle. Some of these methods, and their applications in reprocessing, conversion, and fuel fabrication are summarized in Table $X$. 
TABLE X. NDA Methods for Nuclear Material Accountability

\begin{tabular}{lllll}
\hline & \multicolumn{4}{c}{ Applicability } \\
\cline { 2 - 4 } & Enrichment & Reprocessing & Conversion & Fuel Fab \\
\hline A Monitor & $\mathrm{X}$ & $\mathrm{X}$ & $\mathrm{X}$ & \\
Abs. Edge & $\mathrm{X}$ & $\mathrm{X}$ & $\mathrm{X}$ & $\mathrm{X}$ \\
Y Ray & $\mathrm{X}$ & $\mathrm{X}$ & $\mathrm{X}$ & $\mathrm{X}$ \\
Neutron & & $\mathrm{X}$ & $\mathrm{X}$ & $\mathrm{X}$ \\
Calorimetry & & & $\mathrm{X}$ & \\
\hline
\end{tabular}


a. Alpha Monitors: In-Line alapha monitors were originally designed as a process-control instrument to determine if waste streams from reprocessing, solvent-extraction processes were discharging excessive amounts of plutonium. Some discrimination of beta/gamma radiation from al pha particles is obtained through detector-cell-electronics optimization.

b. Absorption-Edge Densttometry: Both $\mathrm{K}$ and $\mathrm{L}_{\mathrm{III}} \mathrm{x}$-ray absorption-edge densitometry have been proposed for In-1ine measurements of nuclear materlal.

The K-edge technique is applicable for concentrations between 20 and $500 \mathrm{~g} / \mathrm{L}$. It uses a radioactive source tallored to the element to be determined: $75 \mathrm{Se}-5 \%$ Co for determining plutonium. The LIII-edge technique is applicable for concentrations between 1 and $40 \mathrm{~g} / \mathrm{L}$. It uses primary radiation from an $x$-ray tube, secondary radiation from fluorescor designed for the element to be determined, bremsstrahlung sources, or radioisotopes. A crystal spectrometer arrangement can serve as a monochromator or as a coarse energy filter.

c. Gamma-ray Em1ssion: Passive gamma-ray NDA is based on the measurement of the intensity of a gamma ray emitted by the radiolsotope of interest in tire sample being examined. The central problems in the NDA of samples by this technique are the correction for sample self-attenuation, and the interference of compton scattering in the case of high radiation background.

This technique is used in two operating assay systems, one that assays the plutonium and the other the uraniun content in solutions. Both systems use $\mathrm{Ge}(\mathrm{LI})$ detectors with standard high-resolution electronics, multichannel analyzers, and minicomputers for data collection and analysis.

The plutonium system is designed primarily to measure ${ }^{23{ }^{9}} \mathrm{Pu}$ over a range of plutonium concentrations from $0.1 \mathrm{~g} / \mathrm{L}$ to the maximum possible at $500 \mathrm{~g} / \mathrm{L}$. Besides a ${ }^{239} \mathrm{Pu}$ assay, it also provides a useful measure of ${ }^{240} \mathrm{Pu},{ }^{241} \mathrm{Pu}$, $241 \mathrm{Am}$ and, to a lesser extent, $238 \mathrm{pu}$. Assays are based primarily on the $129.3-\mathrm{keV}$ and $413.7-\mathrm{keV}$ gamma rays of $23{ }^{9} \mathrm{Pu}$, w1 th the useful gamma rays from the other isotopes falling between these values. A half-hour sample count gives ${ }^{239} \mathrm{Pu}$ determinations with relative standard deviations (RSDs) of $\sim 1 \%$ for solutions with plutonium concentrations of $\sim 0.1 \mathrm{~g} / \mathrm{L}$ and $\mathrm{prec}$ isions of about $0.5 \%$ for plutontum concentrations of $\sim 5.0 \mathrm{~g} / \mathrm{L}$. With material concentrations between 0.5 and $2.0 \mathrm{~g} / \mathrm{L}$ and one hour counting times, RSDs are reported roughly as follows: $238^{8 u}-2 \%, 239 \mathrm{Pu}-0.05 \%, 240 \mathrm{Pu}-0.4 \%$, and $241 \mathrm{Pu}-0.05 \%$.

The uranium-solution assay system measures the $235 \mathrm{U}$ content in $20-\mathrm{ml}$ samples with uranium concentrations of 1 to $50 \mathrm{~g} / \mathrm{L}$ by counting the 185.7-keV gamma rays. The obtainable precisions and counting times are comparable to those of the plutonium system.

d. Neutron Methods: Neutron coincidence counting and active neutroninterrogation techniques are being developed as potential sensors in assaying spent-fuel fissile content directly. As these sensors develop and the precision of measurement improve, the data input would be processed as described in the IAEA Reference System.

Some applications of the NDA techniques described in the section for a reprocessing-conversion facility are listed in Table XI. 
TABLE XI. Possible NDA Applications for Reprocessing Plant Solutions

\begin{tabular}{ll}
\hline Area & \multicolumn{1}{c}{ Method } \\
\hline Dissolver & Gamma emission, x-ray fluorescence \\
1BP tank & $\begin{array}{l}\text { X-ray absorption edge densitometry } \\
\text { Gamma emission, } x \text {-ray fluorescence }\end{array}$ \\
U product & $\begin{array}{l}\text { X-ray absorption edge densitometry } \\
\text { Gamma-ray absorption }\end{array}$ \\
$\begin{array}{l}\text { Pu product } \\
\text { Recycle acid } \\
\text { (Pu purification area) }\end{array}$ & X-ray absorption edge densitometry \\
$\begin{array}{l}\text { Recycle solvent } \\
\text { (Pu purification area) }\end{array}$ & Gamma emission, x-ray fluorescence \\
\hline
\end{tabular}


An Integral part of the system would be a rigorous standards and measurement control program that ensures the credibility of the assay data. The program would provide quantitative limits-of-error information and would ensure that the individual instruments function properly by checking their precision and calibration accuracy. The callbration history of each instrument may be stored as a permanent record for near-real-time comparison of past, present, and future performance. In some cases, diagnost1c procedures would be incorporated as an integral part of the instrument independent of the central computer. For example, high-resolution gamma-ray systems commonly would have a built-in gamma source for counting-loss corrections.

An 1mportant additional safeguards aspect to utilizing NDA techniques as part of the materials accountancy system, is that in the process it inherently maintains a direct continuous-survelliance on the fissile materials flow.

The above concepts, together with the hardware and software necessary for their implementations are currently beling developed by the Los Almos Sclentific Laboratory (LASL) 28,29 for most facilities in the nuclear fuel cycle. Prototypical near-real-time assay instrumentation and data acquisition systems are being evaluated on industrial-scale unit processes as part of LASL's DYMAC (Dynamic Materials Accounting) program including the DYMAC Demonstration Program. ${ }^{30}$ Near-real-time materials control and accounting systems and/or experlments are being developed at several forelgn facilities, Including Chalk River, Canada (INMACS), Toka1-Mura, Japan (PNC), Karlsruhe, Federal Republic of Germany.

\section{B.2.1.2 Analytical Chemistry Assay: Chemical methods for}

the determination of plutonfum and urantum ${ }^{31}$ can be classified as gravimetric, spectrophotometric, electrometric, mass spectrometric, alpha spectrometric, and fluorimetric. These six methods can be used to determine (1) major constituents in the dissolver solutions and product tanks and (2) minor constituents in recycle streams and wastes. The methods will be discussed briefly as they are used in a safeguards system for fuel reprocessing-conversion facilities, 1sotopic enrichment factlities, and fabrication facilities. Chemical assay procedures for measurements of materials to be safeguarded in various process streams within a fuel cycle and their areas of application are summarlzed (not exhaustively) in Table XII.

a Gravimetric Methods: Gravimetric methods rely on separating a compound of the element to be determined and igniting it to a constant-weight stoichiometric compound. The method is used for determining the content of uranium in nitrate solutions, oxides, and UF 6 . The method is applicable only to relatively pure materials; 1mpurities must be determined using spectrographic or other procedures and corrections applied to the final weight by difference.

b. Spectrophotometric Methods: Spectrophotometric methods rely on the principle that a compound in solution will absorb a quantity of light of a specific wavelength proportional to the concentration of the measured species. 
TABLE XII. Application of Chemical Assay Procedures

\begin{tabular}{|c|c|c|c|c|}
\hline \multirow[b]{2}{*}{ Procedure } & \multicolumn{4}{|c|}{ Applicability } \\
\hline & Enrichment & Conversion & Fabrication & Reprocessing \\
\hline Gravimetry & $\mathrm{x}$ & $x$ & $\mathrm{x}$ & $\mathrm{x}$ \\
\hline $\begin{array}{l}\text { Chemical Redox } \\
\text { Titrimetry }\end{array}$ & $\mathrm{x}$ & $\mathrm{x}$ & $x$ & $\mathrm{x}$ \\
\hline $\begin{array}{l}\text { Electrochemical } \\
\text { Titrimetry }\end{array}$ & $\mathrm{x}$ & $x$ & $\mathrm{X}$ & $x$ \\
\hline Spectrophotometry & & & & $\mathrm{x}$ \\
\hline $\begin{array}{l}\mathrm{X} \text {-ray Fluorescence } \\
\text { Spectrometry }\end{array}$ & & & $\mathrm{X}$ & $\mathrm{x}$ \\
\hline $\begin{array}{l}\text { Radiochemical } \\
\text { Counting }\end{array}$ & & & & $\mathrm{x}$ \\
\hline Isotope Dilution & & & & $\mathrm{x}$ \\
\hline
\end{tabular}


The spectrophotometric methods for trace concentrations of urandum are of interest for determining uranlum in waste streans and possibly in the final plutonium product. The determination of uranium with PADAP has been modified specifically for determind uranium in reprocessing-plant waste streams and in plutonfum ndtrate and oxide products.

The differential spectrophot metric method for detemining plutonium can be used for plutonium-nitrate product with precision equivalent to that obtainable by the best electrometric methods.

c. Electrometrlc Methods: Both uranium and plutonium can be determined with high precision and accuracy ising titrations involving oxidationreduction reactions. These methods generally are classified by the method used to detect the titration end point as potentiometric, amperometric, or coulomet ric.

Controlled-potential and constant-current coulometry are well-established methods for determining uranium and plutonium in solutions. The methods are based on the principle that the weight of a substance oxidized or reduced at an electrode is proportional to the quantity of electricity (coulombs) passed through the electrode.

d. Mass-Spectronetric Methods: In most existing reprocessing plants, thermal ionization mass spectrometry is used to determine the amount of each 1sotope of uranium and plutonfum, and consequently the effective atomic weights for calculating total uranium and plutonium from chemical analyses of samples from the accountability tanks. Isotope-dilution mass spectrometry can also be used to measure the plutonium and uranium concentrations in the tanks.

e. Alpha-Spectrometric Methods: Quantitative alpha-particle spectrometry is based on measuring the Intensity of the alpha radiation of the sample. The alpha particles are ejected with discrete energies, and for uranium, neptunium, plutonium, and americium isotopes characteristic of the nuclear fuel cycle, these energies range from 4 to $5.5 \mathrm{MeV}$. The method has been applied to the determination of plutonium in dissolver solutions following solvent extraction separation of the plutonium.

f. X-ray Fluorinetric Method: The HEDL development of the Fuels Assay $X$-ray System (FAXS) employs an energy dispersive $X$-ray fluorescence analyzer to measure $U$ and $\mathrm{Pu}$ with better than $0.5 \%$ RSD precision in a total analysis time of 2 to 4 minutes. To optimize precision in this short interval a high count rate for excited $x$-rays must be obtained. In fAXs, this is done using dual detectors and a very "close" geometry between exciting $x$-ray source, sample, and detectors.

\section{B.2.1.3 Measurement Precision and Accuracy: The precision}

of measurements is essential to limit the uncertainty in the quantities of materials being measured. The currently applied analytical chemistry methods for nuclear material: accountability have measurement precisions ranging from relativc standard devlations (RSD) of typically $0.05 \%$ for gravimetric methods, $0.1-0.25 \%$ RSD for titrimetric methods, and $1-10 \%$ for spectrophotometry (with further development, may be improved to better than 
0.5 RSD). The HEDL development of the fuels assay $x$-ray system (FAXS) indicates a U.5\% RSD. These precisions in some cases are state-ot-the-art methods now used by most laboratories and have resulted from several ycars of extensive effort to achieve the routine precision indicated. Accuracles of these assay procedures depend on suitable standards and adequate standards which must be malntained for mixed oxide material. Consequently, it is assumed that a total accuracy of measurement is the range of $0.5-1 \%$. This accuracy may be adopted for the NDA technique, in estimating error margins in material tlow throughout the FBR fuel cycle.

The above measurement techniques (with related preclsions) being developed for LWR enrichment, conversion, fabrication and reprocessing facilities are directly applicable to the $k$ BR reference fuel cycle.

B.2.1.4 Conversion Facility: The conversion of plutonium nitrate to commercial plutonium oxide, 32 carbide or metal is the 1 inal stage of the reprocessing operation. For safeguards concerns the plutonium nitrateto-oxide conversion facility is an important component of the closed LWR and FBR nuclear fuel cycles. It is the intermediate state between the spentfuel reprocessing and fuel fabrication facilities and as a consequence processes large quantities of plutonium in both liquid and solid forms. Huwever, safeguards sensor systems designs are not expected to differ between closed LWR and FBR fuel cycle reprocessing-conversion facilities.

The end product of mixed oxide powder would have to be packaged into an item-accountable container designed for safeguards concern in the accountability and control of the fissile material and in the transport of the oxide to the fuel assembly fabrication facility when the fabrication is not colocated with the reprocessing and conversion complex. Accountability, and control techniques involving both NDA and chemical and nuclear methods should probably be applied at both shipping and receiving stages.

\section{B.2.2 Isotope Correlations and Measurement Techniques: Isotope} correlations and measurement techniques have the potential as a safeguards accountability measure in the dissolver stage of the muclear fuel cycle. Throughout the major portion of the fuel cycle, the fissile accountability is basically in the form of item accountability (fuel powder containers, pellets, elements, and assemblies). The measurement of the material balance input and product in the reprocessing phase of the cycle is the primary direct fissile material flow verification. The materials balance accountability gap which exists between the fabrication plant output and the input to the reprocessing plant can be minimized by the utillzation of Isotope Correlation Techniques (ICT) at the dissolver stage of the processing plant. The safeguards significance of the ICT is that the input accountability would allow a level of verification of the fabricators' uranium and plutonium isotopic content specification, the irradiation history, and the subsequent spent fuel assembly flow to the reprocessing plant.

\section{B.2.2.1 Isotope Correlations: The isotope correlation functions} which are currently being considered as most effective for safeguards purposes, involve combinations of 1sotopic concentrations that exhibit a reasonably monotonic behavior over a broad range of reactor conditions and burnup. Some of these funtions are: Pu/U vs. depletion $235 \mathrm{U}, \mathrm{Pu} / \mathrm{U}$ vs. $(100-239 \mathrm{Pu}), \mathrm{Pu} / \mathrm{U}$ vs. $239 \mathrm{Pu} \times 242 \mathrm{Pu} / 240 \mathrm{Pu}^{2}$, and $236 \mathrm{U}$ vs. $235 \mathrm{U}$. The 11 near relat lonships being 
Independent of reactor operating conditions and burnup, effect a means of verifying the input to a reprocessing plant, and methods for establishing internal consistency of input analytical measurements, and a level of verification on initial isotopic concentrations prior to burnup. Some of the suggested functionals also include fission product lsotope correlations in addition to the major and minor isotopes of uranium and plutonium.

B.2.2.2 Measurement Systems: The selection of the more safeguards effective functionals will depend not only on the level of reliability for verification, but also on the capability and difficulty of developing measurement methods. Proposed measurement techniques cover the general areas: (1) simultaneous multicomponent analysis techniques, (2) ion-cyclotron-resonance mass spectrometry, (3) x-ray fluorescence or densitometry with high flux monochromatic $x$-ray sources and high dispersion spectrometers (4) synchrotron radiation, and (5) active neutron interrogation.

Most of the proposed systems are capable of measuring the elemental ratio, $\mathrm{Pu} / \mathrm{U}$. However, only a limited number of systems appear to have the capability of determining the isotopic correlation functions of interest. Assessments of measurement systems should include the capability of isotopic measurements and the potential that a measurement system can be developed for on-line or near-real-time assay of the dissolver solution. The application of the measurement techniques under actual operating conditions would be a primary objective of a development program.

B.2.3 Containment and Surveillance: Containment and surveillance functions applicable to reprocessing and conversion facilities would consist primarily of nuclear materials movement and/or handling integrity. The $\mathrm{c} / \mathrm{s}$ measures would utilize optimum positioning of closed circuit T.V., radiation monitors, and portal monitors to assure recording of any unplanned changes in the content or location of nuclear materials, maintaining integrity of agency instrumentation and devices, and integrity of samples, packages or seals. The plant design should include features that would enhance specifically the safeguards effectiveness by accommodating the safeguards system.

B.2.4 Impact on Safeguards Techniques from High Burnups, Sodlum, and Radiat lon Spiking: The FBR reprocessing aspects differing from the LWR spent fuels are mainly in the high burnup and the presence of sodium. The high burnup fuels have been reported to result in a higher fraction of plutonium to remain dissolved after leaching in the dissolver tank (about $1.5 \%$ in FBR to $0.04 \%$ in LWR of total plutonlum). Therefore the safeguards techniques on the waste stream should be developed with more stringent identification and accountability balance determination of the fissile material. The presence of sodium does not appear to impact on safeguards concerns, since it would only require a modification to the head-end stage of the reprocessing system for complete removal of the sodium under an inert and controlled environment. The problems with the removal of residual sodium are not expected to effect any significant safeguards difference between the LWR and FBR reprocessing systems.

A measure of effective safeguards is the degree of compromise to the accuracy, precisicn, or even operational feasibility in flssile materials accountability techniques that results from introducing the "denatured" and/or "radiation spiked" fuels as alternate fuel technologles. 
The safeguards concern is that the IAEA safeguards systems of direct fissile identification and accountabllity via analytical-chemistry assay or nondestructive assay via neutron or gamma-ray sensors would be compromised if not made completely nonfunctional. In the NDA system, the continuous on-1ine direct Identification of the fissile isotopes in the bulk flow, is affected by the measurements of the gamma-ray spectra unfque to the fissile 1sotope. These "radiation signatures" are completely submerged in the radiation-noise background of the gamma-ray fields from the fission products, from added spikants at lethal dose levels, or from the $232 \mathrm{~J}$ daughter chain in thorium fuel cycles.

B.3 MOX Fabrication and Scrap Recovery: The implementation of IAEA safeguards to MOX fabrication and scrap-recovery facilities have been considered for the LWR plutonium-recycle systems. The base-case MOX fabrication facility usually assumes a nominal production capacity of 200 tonnes/yr, with a plutonium content of about $4 \%$. The reference MOX fabrication facllity for the FBR fuel cycle would be a plant process capacity of about 100 tonnes/yr with a plutonium content of about $16 \%$. This is consistent in plutonium flow rate with the reference fuel reprocessing plant capacity of 200 tonnes/yr. The reference manufacturing process requires storage capability for feed powder, process IIne buffer, finished fuel pins, and completed assemblies. In addition, accumulation points are required for clean (dry) and contaminated (wet) scrap. For normal operation, in-process inventory other than storage may be assumed to be $400 \mathrm{~kg} /$ day of fuel (containing $16 \% \mathrm{Pu}$ ), resulting in daily Pu throughput of $64 \mathrm{~kg}$.

The safeguards considerations are therefore not significantly different in total plutonium throughput when compared to the LWR fabrication plant. The higher concentration of plutonium in the FBR MOX pellets, fuel pins and fuel assembly would not affect the selection and performance characteristics of the sensors in an IAEA near-real-time Safeguards System. The contalnment/surveillance componente of the coordinated safeguards system would parallel the design considerations of the safeguards systems planned for the LWR fabrication facility and of the LWR and FBR reprocessing facilities. The design and development of the material-accountancy (NDA and Chemical Analysis) components of the safeguards system would be similar to those used in the reprocessing plant. The higher plutonium concentration in the fuel would enhance the measurement accountancy methods in determining directly the fissile 1sotope contents.

\section{B.4 Bulk Plutonium Storage and Intraplant Transportation: A safeguards} system for bulk plutonium must consider the plutonium packaging area, the vault storage area, and the intraplant transportation of plutonium. An on-1ine computer1zed bulk "Plutonium Protection System" (PPS) ${ }^{35}$ has been developed in the U.S. and is being operationally evaluated at the Hanford Plutonfum production and processing facility. All procedures in PPS are monitored by closed-circuit T.V. (CCTV) and by a computer system. In the packaging area, the plutonium cans are further sealed into an overpack container into whose upper half $\log i c$ circuits and sensors are integrated to provide unit identification, to monitor temperature and can distortions, and to detect tampering. Electronic 1dentification codes are set in each container after registering the weight of the contents. In the vault storage area, containers of plutonium are stored in secure storage modules. Detection and monitoring systems are provided in the 
vault area to ensure that activities are proceeding as authorized. Several access control methods such as electronic credential readers, CCTV, electronic scale, metal and nuclear material detectors are implemented. A secure intraplant transportation truck which contains the necessary physical and electronic design features to maintain physical control and accountability during material movement, is used to move bulk plutonium.

The IAEA Safeguard System for bulk plutonfum may include one or any combination of the following three concepts.

a. Periodic IAEA Inspection: IAEA personnel will perfodically inspect the accounting records of the plutonium packaging area and the vault storage area for material accountabllity, and inspect the sensors and other instruments to establish integrity.

b. Continuous IAEA Inspection: The IAEA inspector at the facilfty will be notified of all required plutonium movement operations in the plant. The inspector will also be responsible to see that up-to-date accounting records are malntained in all areas where bulk plutonium is handled.

c. IAEA Remote Survelllance: IAEA Remote Survelllaace Safeguard System (to be described in Section $V-D$ and $E$ ) may be interfaced via communication links to the data collection and control centers in PPS using tamper-indicating techniques. This will provide on-line near-real-time monitoring of bulk plutonfum in the facility.

B.5 Application of IAEA Safeguards During Transportation: The type of materlal being transported determines the level of IAEA goals the safeguards system should approach. Presented below are three concepts for safeguarding nuclear material in transit. These concepts do not vary with respect to the distance traveled, but with the time-interval goal for verification and the avallable safeguards measures.

B.5.1 Periodic Shipping/Receiving Comparison: Thls concept is based on the comparison and correlation of material transfer records at the origin and destination of shipments, and on the accountancy records maintained at a monitoring agency. The key elements are:

-Notification to the IAEA by the shipper of the transfer and verification by the IAEA of the form and quantity being shipped,

-Use of seals and integrity devices by the IAEA to ensure the integrity of the shipping container or cask and the material contained to provide the IAEA with continuity of knowledge.

-Notification to the IAEA by the recelver of the recelpt, and verification by the IAEA of the form and quantity of the nuclear materlals received.

The timeliness of detection goal of the IAEA should be no less than the transit time. For nuclear material with short timeliness goals, the above procedures may be inadequate, and additional methods may be needed. 
B.5.2 IAEA Escorts: Th1s concept assumes continuous LAEA escort of the transportation vehicle from the point of origin to the destination. The key aspects of this system may include:

- Perlodic notification to the IAFA headquarters, by standard telephone or radio, of the position of the transportation vehicle and the integrity of material containment,

- On-site observation of loading, unloading, and IAEA verification of transported nuclear mterial, and

- Use of seals and integrity devices by the IAEA to ensure the integrity of shipping container or cask and the material contained.

This concept has a capability for rapid detection of anomalies in the shipment during transit.

B.5.3 Remote Survelllance: Th1s concept is based on a monitoring system that verifies, by a remote communication link, the presence and integrity of the material in 1 ts container during its transit between the origin of shipment and destination. The information of interest is the location and status of the shipping cask or contalner. To achieve this requires transport vehicles which are constructed of penetration-and accidentresistant materials and which have onboard the position location modules that can communfcate with the IAEA remote-surveillance station by remote communication links. In addition, varlous sensors, depending upon the material transported, need to be developed to ensure cask or container integrity. Conceptual designs for transport vehicles, containers, and material-accounting sensors have been developed for LWR spent-fuel assembly transport and the bulk plutonfum transport. A comparable system would be adopted for fresh and spent FBR assemblies. With this system nearly instantaneous detection of anomalles could be achleved, depending only on the time interval chosen for communication. Since this type of surveillance is in the conceptual stage, feasibility evaluations and demonstration will be required before implementation on an international basis. 


\section{ADVANCED IAEA SAFEGUARDS RESEARCH AND DEVELOPMENT}

\section{OBJECTIVES}

IAEA safeguards are the primary measures of reducing the risk of pro11 feration in the worldwide deployment of nuclear power. Technical and institutional differences in the proliferation risks between the many fuel cycles can be minimized by the introduction of improved safeguards on commercial nuclear activities. It is evident therefore, that effective IAEA safeguards are an essential feature and an important additional dimension to be considered in the development and deployment of nuclear power systems.

The current safeguards related efforts have been aimed at the implementation of safeguards systems to the five basic phases of the fuel cycle; uranium enrichment, thermal and fast power reactors and fuel handiing systems, commercial-scale reprocessing of spent fuel, mixed oxide fuel fabrication, and interim storage of Irradiated uranium and/or separated plutonium. The objectives of these safeguards measures are to provide a timely detection of the diversion of significant quantities of nuclear materlals from peaceful nuclear activities and consequently affect a measure of deterrence of such diversion by the risk of early detection

The safeguards systems currently employed have been based on material accountancy supplemented by containment and surveillance measures. Although the experience with these methods has indicated a general capability of providing effective international safeguards, these procedures appear to be inadequate to meet the significant quantity and timeliness goals and guidelines of detection which are advocated $r y$ some member states of the IAEA for the anticipated deployment of large scale nuclear facilities.

Potential improvements in the accuracy of measurements by analytical chemistry assay and/or nondestructive assay (NDA) techniques are essential to meeting the materials accountancy goals and guidelines but would not impact on the timeliness goals.

A necessary, but not sufficient, condition to satisfy the timeliness goals is the research and development of advanced nondestructive assay methods which essentially applies nuclear physics, nuclear chemlstry, and instrumentation to the measurement of nuclear material in a more near-real-time mode. The sufficiency condition will be satisfied by the research and development of advanced containment/surveillance methods to complement materials accountancy. The objective of timely detection will necessitate materials inventory verification and accountancy integrity by the implementation of containment/surveillance measures at strategic points between key measurement positions.

The 1mplementation of the proposed advanced components of safeguards in to an operable on-1ine near-real-time IAEA Safeguards system will depend on continuing and expanding the safeguards research and development program. The general technology program Includes a broad range of developments designed to provide the IAEA with advanced measurement and accountancy technology, data analysis, and contalnment/survelllance capabilities. Although the partial listing of some $R \& D$ requirements refers mostly to advanced 
sensor intrumentation, a major area of effort would have to be directed toward determining the optimum integration of sensor components coupled into a safeguards system design and applied to operating facilities in order to establish the operability under plant conditions.

\section{A. Materials Control and Accountancy}

The effort in developing and evaluating analytical techniques for measuring plutonium and uranium have been based mainly on commercial processcontrol considerations. The R\&D programs in chemical assay and NDA techniques are now exphasizing the advanced safeguards requirements and, where possible, developing methods to satisfy both process control and safeguards. The precision and accuracy of the measurement methods are in some cases directly dependent on the accuracies of physical and chemical constants such as the half-life of the fissile isotopes. The R\&D program should therefore include improving the accuracies of these and other necessary critical basic constants. The advanced sensor techniques and technology developments include:

\section{A.1 Analytical Chem1stry Assay}

a. Fuels Assay X-Ray System (FAXS): The operational use of the $x$-ray fluorescent technique introduces a rapid-turnaround time in the chemical technique for uranium and plutonium in breeder fuels.

b. Amperometric and Coulometric Methods: Accuracies of these assay procedures depend upon suitable standards. Adequate standards for mixed oxide materials $\left(\mathrm{PuO}_{2}\right.$ and $\left.\mathrm{UO}_{2}\right)$ are a continuing developmental program.

c. Resin-Bead Techniques: Demonstration of the resin-bead collection technique for using microgram quantities for independent off-stte chemical analysis or onsite at reprocessing-conversion plants, fabrication facilities, or unirradiated and irradiated fuel storage facilities.

d. Isotopics: Isotope correlation techniques for dissolver solution, unirradiated and irradlated fuel storage sampling assay.

\section{A.2 Advanced NDA Techniques for Safeguards Systems}

a. Gamma-ray assay of plutonium content in wet (on-1ine) and dry waste streams.

b. X-ray fluorescence in radloactive dissolver solution.

c. High-resolution gamma-ray spectrometry for 1sotopic analysis of plutontum in solution.

d. Gamma-ray absorption to determine plutonium concentration in the presence of uranium.

e. Nondestructive-analysis techniques for use in waste solidification technology should be adopted. 
f. Active and passive neutron interrogation technique developments should be advanced toward implementation as potential sensors In assaying fissile content directly and independent of form 1.e. bulk (powder or metallic), unirradiated and irradiated fuel assemblies, mixed-oxide pellets, and/or reprocessing solutions.

g. Development of measurement techniques for on-line near-real-time assay should include: simultaneous multicomponent isotopic analysis techniques, $x$-ray fluorescence or densitometry with high energy or wavelength dispersion spectrometers, and active neutron interrogation.

B. Containment/Surveillance

Some of the $\mathrm{C} / \mathrm{S}$ sensor development and evaluation programs should include:

\section{B.1 Crane Monitor System:}

a) The ability to determine optimum techniques for monitoring crane loads. b) The utility of crane load, direction of travel position, and activity information in assessing fuel handling operations. c) The automation and rellability of the above parameters over long periods of time.

\section{B.2 Storage Acoustic Monftor:}

a) Determination of the unique acoustic signals of fuel handing in storage pools. b) Development of hardware and software to Identify fuel handling acoustic signals with acceptable possibilities of detection and false alarms. c) Development of criteria to correlate detection of fuel handling with possible fuel diversion.

\section{B.3 Fuel Assembly Identification Devices (FAID):}

a) FAIDs having unique ultrasonic signatures that (1) will be altered if the FAID is removed from the fuel assembly, (2) will prevent disassembly while in place, (3) can be interrogated in place, and (4) is compatible with all fuel assembly environment conditions. b) FAID readers that can be positioned over the FAID while it is attached to the fuel assemblies, either as fresh fuel or as irradiated fuel submerged in the pool. c) The establishment of criteria and development of a system for automating the FAID identification process.

\section{B.4 Under-Sodium Viewing (USV) System}

a) Expanding the demonstration program of the ultrasonic imaging (USV) system for use in storage facilities of fresh and spent fuel assemblies on-site or away from reactor sites. b) Demonstrating the applicability of this viewing system in a WaterPool Storage System. 


\section{B.5 Other Systems for further Development Include:}

1. Underwater Optical Viewing System,

2. Cerenkov-Glow Vision Device,

3. Spent Fue1 Scanning for Neutron and Gamma Emission/Burnup, and

4. Spent Fuel Temperature Monitoring.

Interfacility Transportation:

a) Evaluating commercially avallable transportation components that could be used in the system. b) Designing and building system elements using the most sultable components. c) Performance testing the elements under simulated and actual fuel transportation operations.

\section{Input Measurements}

Development of systems for on-line measurements of volume, densities, and temperatures of process solutions.

D. On-Line, Near-Real-Time IAEA Advanced Safeguards System

To optimize the limited resources of the Agency, the possibility of applying and utillzing tamper-indicating data link and data collection modules, either independently or in a verification mode with the SSAC system, w111 be an important consideration in determining the need and feastbility of the near-term application of automated data acquisition systems.

Advanced concepts being developed in the U.S., 28,29,34,35 parts of which can be modified, expanded, and used for IAEA safeguards, includes advanced instrumentation of (1) sensors, (2) data collection modules, (3) communication links, and (4) monitoring and display units. Each of these components may supplement and eventually be phased into the current methods of IAEA site inspections for safeguards related surveillance and verification of materials accountancy. The system would allow the application of on-line near-real-time computer systems. Dne such possible system is schematically presented in Fig. 11 where certain combinations of the components of containment/ survefllance, and material accountancy systems may be placed under national and/or IAEA control. Other options may Include the Data Collection Module under IAEA control, or the total system may be an Independently controlled component of the IAEA.

The advanced IAEA system concept is in principle a generic system and is applicable to all elements of the LWR and FBR fuel cycle; spent-fuel and fresh-fuel storage, plutonium storage, transportation, isotopic enrichment, reprocessing, fabrication, and the transportation of mix-oxide fuels, provided that appropriate sensors be applied or developed based on the characteristic properties of the fuel cycle element to be safeguarded.

The original conceptual design is a system for the containment and survelllance of spent fuel storage, handling and transportation operations on the national level of safeguards concern. In this section the concept is generalized to include all elements of the LWR and FBR fuel cycle. This 


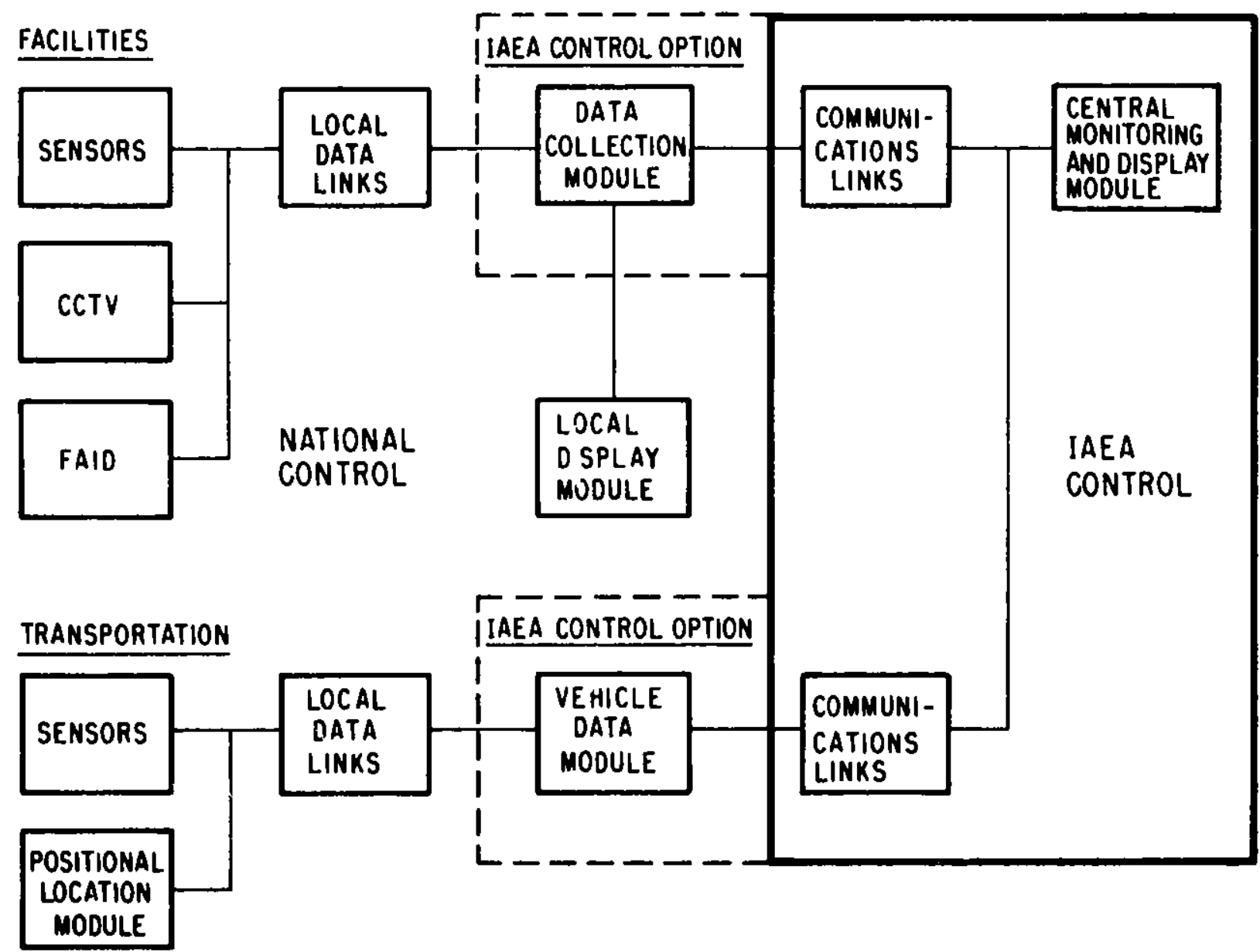

- DETECTION ANO ASSESSMENT ELEMENTS $\longrightarrow$

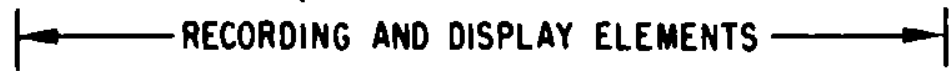

Fig. 11. Conceptual Overview Containment and Surveillance System. 
generalization extends the role of the IAEA Safeguards Systems from the traditional concepts of periodic inspection of the facilities by IAEA inspectors to the concept of continuous or almost continuous inspection. The reference system emphasizes an overall structure in which other computer based on-line systems, such as the near-real-time material control and accountancy, can be Included as one subsystem in this generalized approach.

Factors governing the choice of containment and surveillance (C/S) instruments are (1) the availability of off-the-shelf hardware for each monitor and (2) guidelines developed from facility constraints and performance requirements. The capabilities of the $\mathrm{c} / \mathrm{S}$ system include the following:

1. Detect both reported and unreported movements

2. Provide assessment information for both reported and unreported movements.

3. Provide inventory verification data

4. Operate with a high degree of rellability

5. Allow timely reporting of data

6. Provide tamper-1ndicating capability throughout the system

7. Operate as simply and cost-effectively as possible within preceding constraints.

8. Minimize the impact on facility and transportation operations

9. Minimize the required number of inspectors and Inspections.

E. Description of Reference Advanced Safeguards System:

The reference safeguards system includes advanced instrumentation: (1) sensors, (2) data links, (3) data-collection modules, (4) communication links, (5) monitoring and display units, (6) closed-circuit T.V., (7) the image processor, (8) tamper-indicating techniques, and finaliy, (9) a computer system. Main emphasis is on the on-line near-real-time capability for early detection of diversion and the timely reporting of such diversion.

One characteristic of this approach as shown schematically in Fig. 11, is the separation of safeguards aspects into two categories with some units under national control while others are under IAEA control. The central monitoring units may be thought of as being located at elther IAEA headquarters or at some IAEA regional station if this option is considered feasible. The data links, communication links, and equipment under national control are protected by tamper-indicating techniques. Figures 12 and 13 are schematic sketches of such techniques. Closed-circuit T.V., coupled with the digital image processor, provides an added dimension to the tamper-indicating methods in addition to 


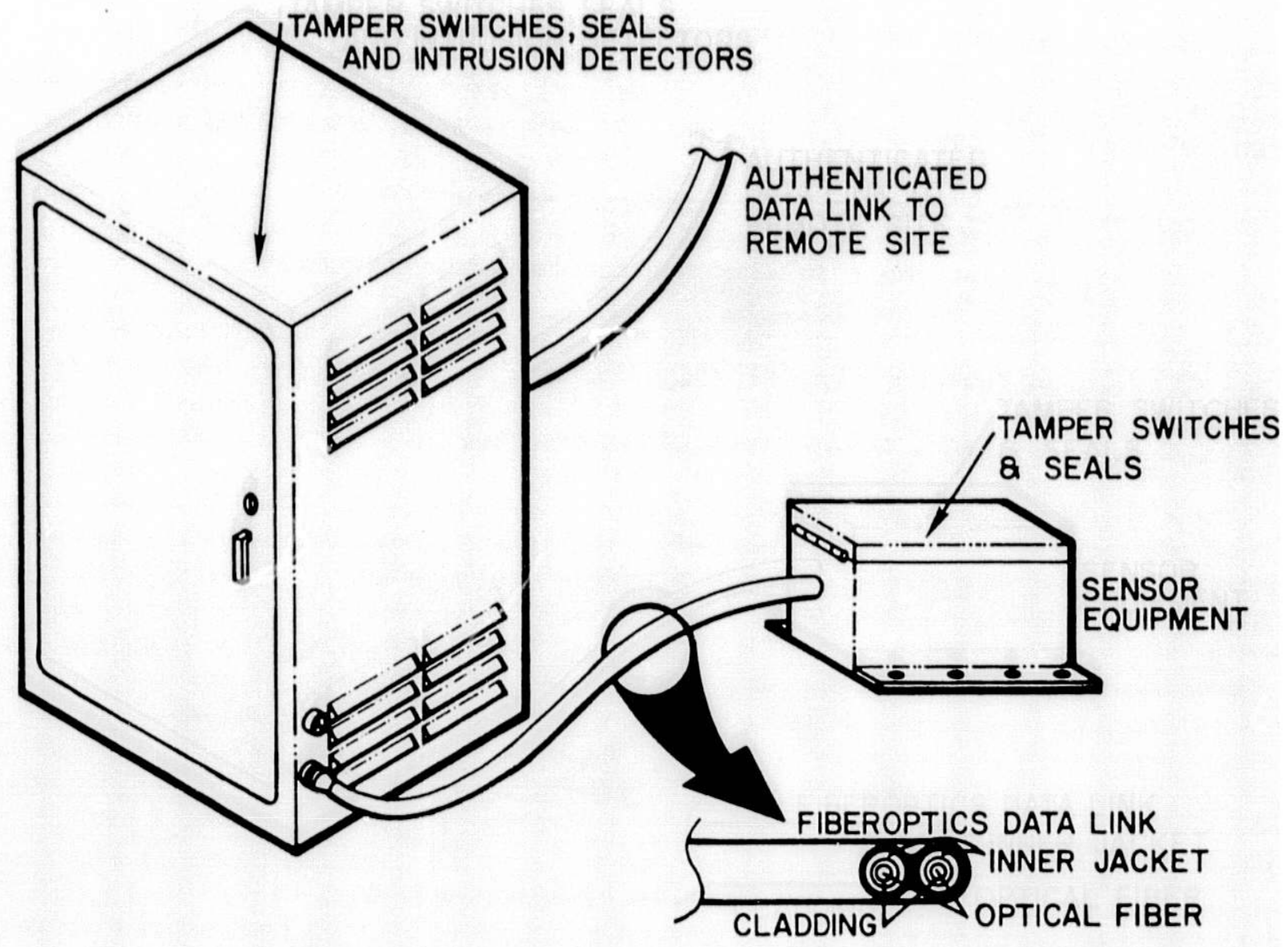

Fig. 12. Tamper-Indicating Techniques. (See ref. 34.) 


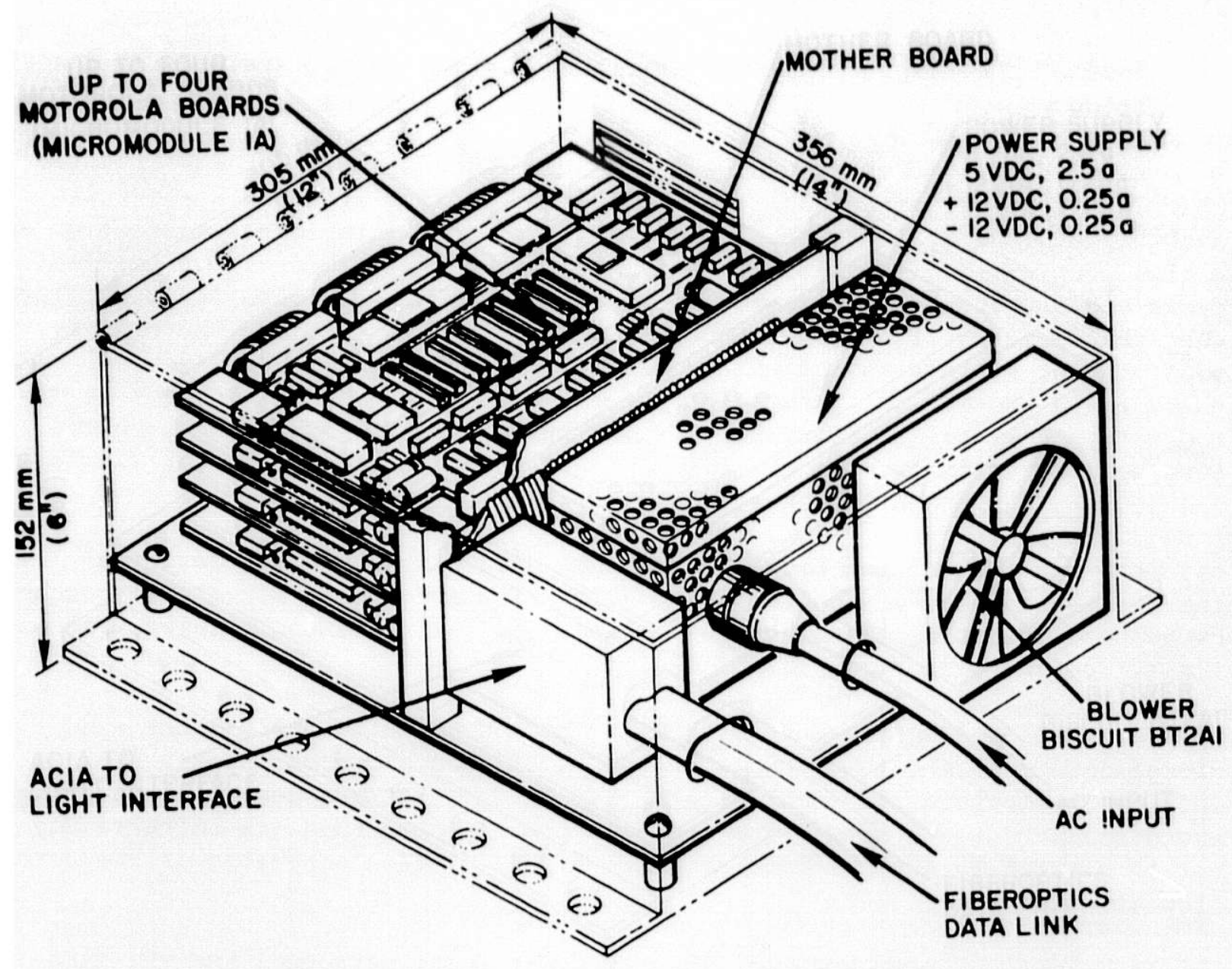

Fig. 13. Tamper-Indicating Sensor Module. (See ref. 34.) 
beling useful in the physical protection phase of the systems being safeguarded. Fig. 14 is a schematic sketch of a closed circuit T.V. system. The datacollection module shown in Fig. 11 has two independent functions: The local display is for the national operation systems, and the other is for the communication of the data to an IAEA central monitoring station. The datacollection module would be designed such that its software could not be altered by the locil personnel.

Some of the components to be developed for the system are briefly described below:

a. Sensors: These would be the instruments designed for the specific characteristics of a phase of the fuel cycle. In the fresh or spent-fuel assembly storage systems, the sensor may be a passive radiation monitor or an active neutron interrogation monitor, the unique characteristic of the fuel cycle element being the emission of radiation. These monitors may he applicable when the assembly fs passed through an access port in entering the storage pool. Other sensors operating on different principles for the same fuel cycle phase would provide an improved safeguard system: for example, acoustic monitors, under sodium vlewing, or underwater optical viewing monitors for sensing fuel assembly movements within the storage pools, or direct viewing, and devices for scanning signatures of assemblies.

b. Data-Collection Links: The local data links transmit data from the sensors to the data collection module. These components would be protected by tamper-indicating techniques and tamper-indicating sensor modules, schemattcally presented in Figs, 13 and 14 .

c. Data-Collection Module (DCM): The DCM collects, correlates and stores data from the instruments in the facilities and communicates the information to both the local display module and the IAEA central monitoring and display module (CMDM). This unit is protected so that its software may not be altered by the local personnel. Figure 15 is a schematic of the data flow at the DCM.

d. Local Display Module: This provides local personnel and the IAEA inspector with a means of obtaining on-site data for assessment.

e. Communication Links: These transmit information from the DCM to IAEA CMDM efther by telephone lines or by satellite lines. An image processor capable of transmitting video data from closed circuit T.V. system is also included. The data from the communfation links is authenticated by using tamper-1ndicating techniques.

f. Closed Circuit T.V. (CCTV): This provides T.V. pictures for storage (a) when the DCM identifies anomalies in the sensor data, (b) upon command by the central monitoring and display module at the LAEA remote station.

g. Digital Image Processor: It allows T.V. data to be stored in a random access memory at video rates. The stored data can then be selectively transferred to the computer and used to drive a communications mode at data rates comparable with phone lines and narrow-bandwidth radio-frequency links. 


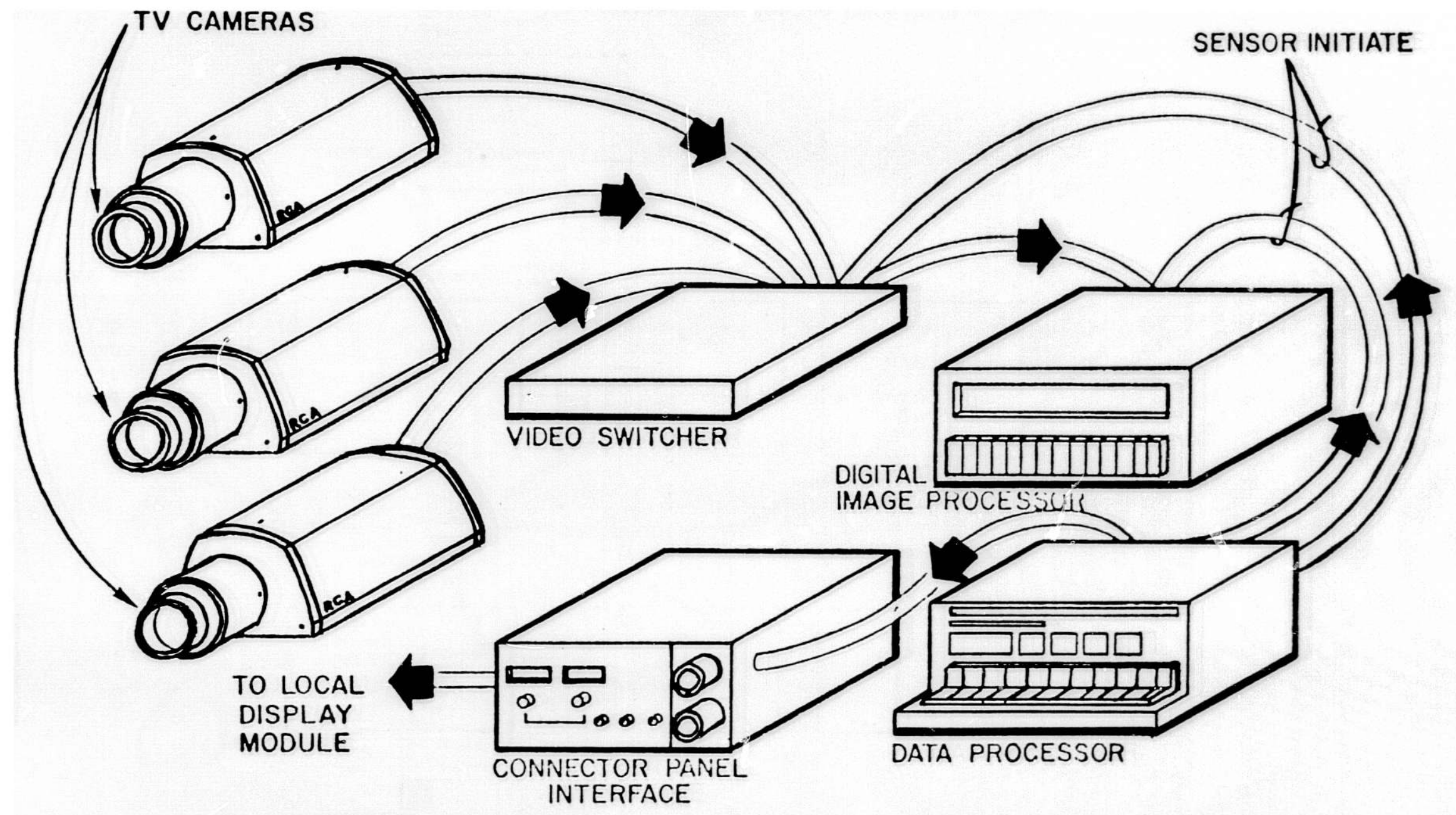

Fig. 14. Closed Circuit T.V. (See ref. 34) 


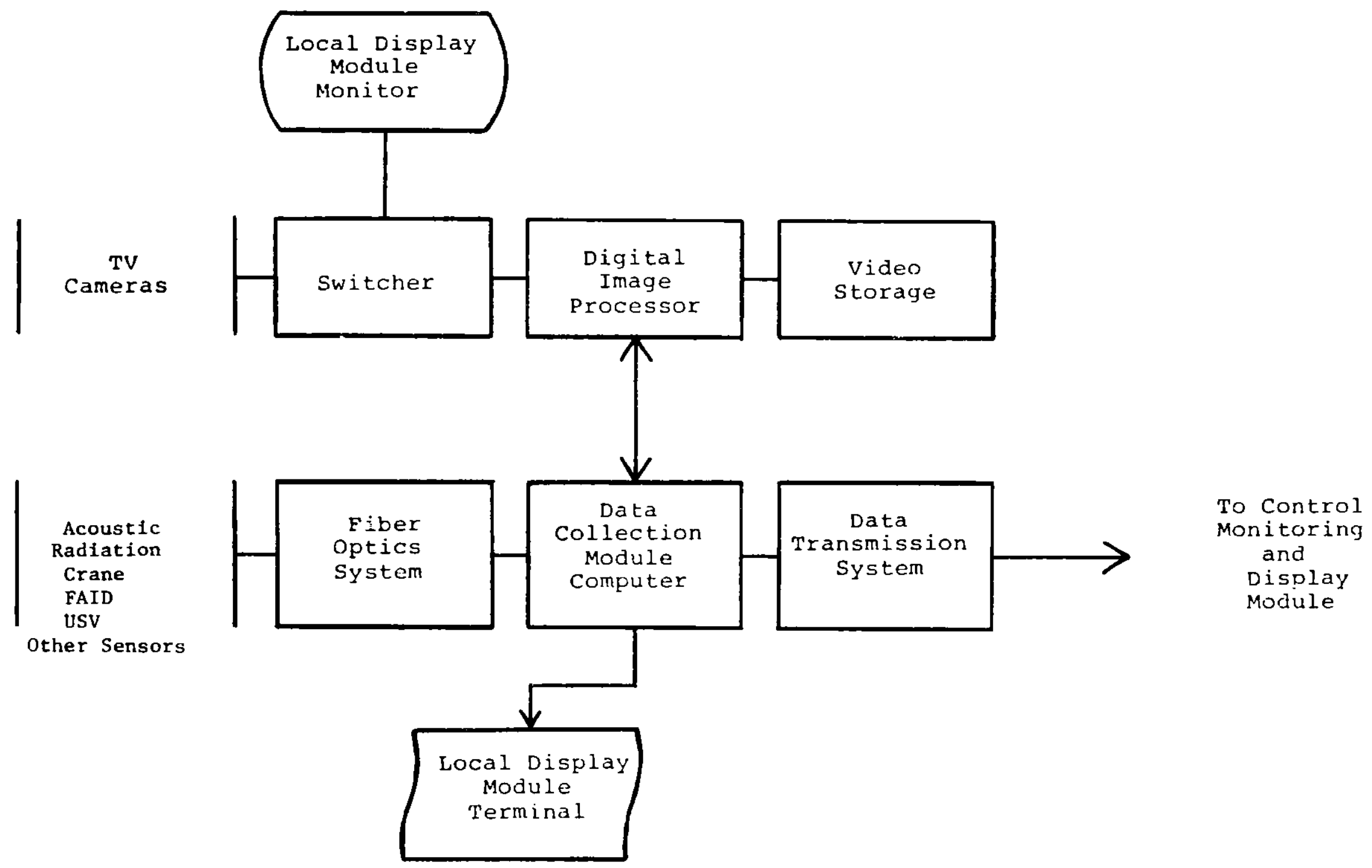

Fig. 15. Data Collection Module Data Flow.

(See ref. 34 ) 
h. Central Monftoring and Display Module: Th1s module receives, interprets, stores, and displays data gathered from different DCM's corresponding to different fuel-cycle elements or phases. Some examples are fuel assembly DCM and transportation DCM. Figure 16 is a schematic of the arrangement and data flow.

F. Implementation of the Safeguards System: The reference advanced IAEA Safeguards System would include inspections in any one or combination of the following modes:

1. Periodic inspection of the fuel-cycle facility by IAEA inspectors to review data acquired by the instruments and verify the material inventories

2. LAEA resident inspector at the facility to review the data and operations and to verify the material inventories

3. Collection of the data by remote techniques as described in this section coupled with periodic on-site inspection of the facility.

The safeguards system for a specific fuel-cycle facility depends upon trade-offs between several factors, two of which are IAEA resources and timeliness of detection. 


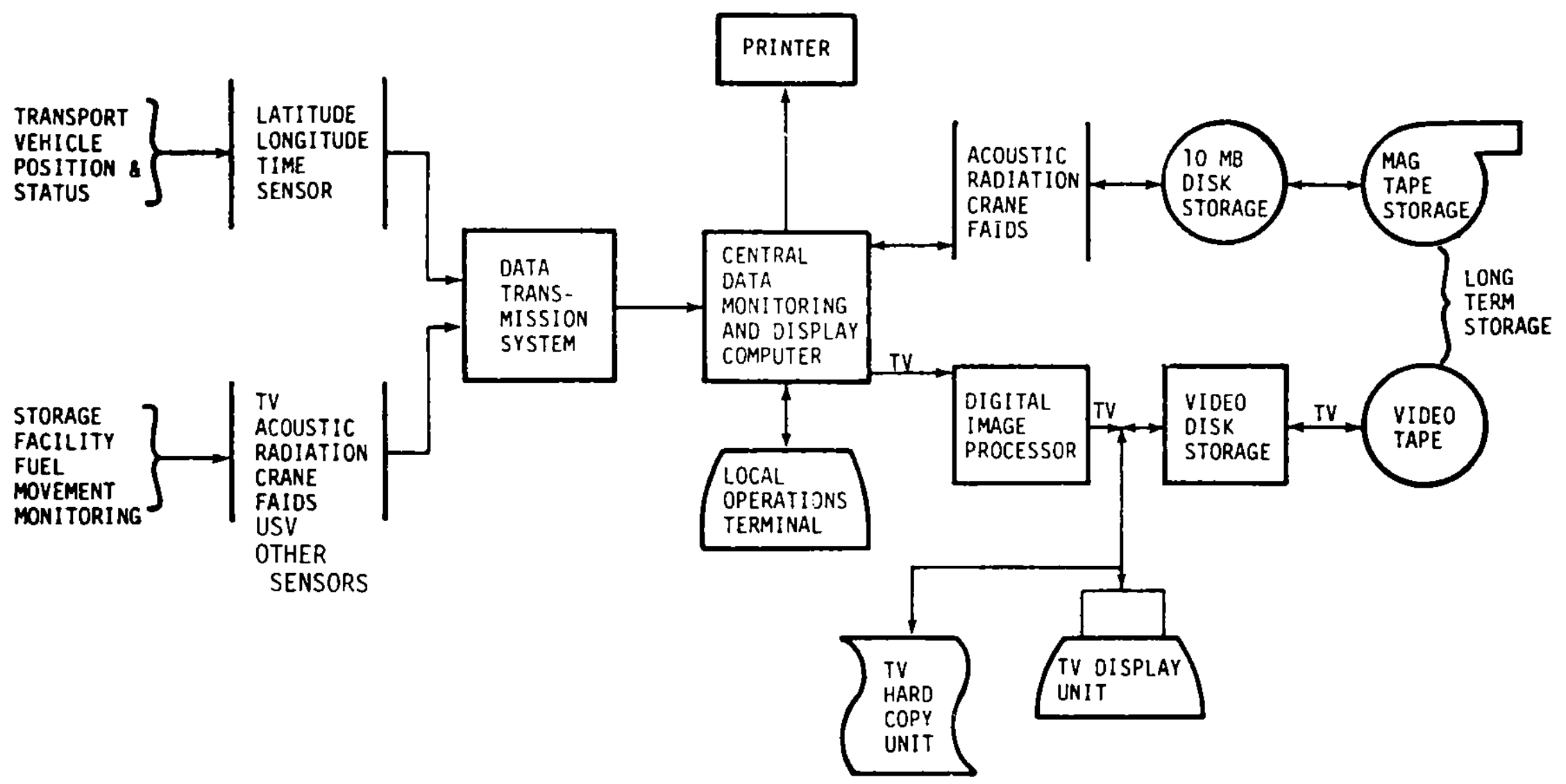

Fig. 16. Central Monitoring and Display Module Data Flow.

(See ref. 34.) 
REFERENCES

1. "Creys-Malvaflle (Super Phen1x) Nuclear Power Station," Nuclear Englneering International, R. Knox, Edttor, p. 43 (June 1978).

2. S. Rippon, "Prototype Fast Breeder Reactors Operating in Europe and the USSR," Nucl. Eng. Int. 20, (231/2), 545-550 (June/July 1975).

3. A.D. Evans and W. Macrae, "Operation of PFR and the Influence Upon the Design of CFR 1," Paper No. 1/9, Nuclex 75, Basel (October 7-11, 1975).

4. J. Le Bouhellec, P. Miquel, A. Redon, and A. Boudry (CEA-France)

"Conceptual Design of a Reprocessing Plant for Irradiated Fast Breeder Reactor Fuels," Trans, Am. Nucl. Soc. 20, 635 (1975).

5. J.W. Moyer, "A Preliminary Safeguards Concept Definition for a FacilityIntegrated, Fuel Cycle Plutonium Transportation Vehicle (PTV) and Shipping Container," Sandia Laboratory, SAND 77-1274 (1977). See also, Fifth Symposium on Packaging and Transportation of Radioactive Materials, Las Vegas, N.M., CONF. 780506 (May 7-12, 1978).

6. Barnwe11 Nuclear Fuels Plant Applicability Study, Vol, I, II, and III, DOE/ET-0040/1 (April 1978).

7. J. L. Vialard, J. Heyraud, and J. Pajot, "Fuel Element Fabrication Plant for Super-Phenix," Trans. Am. Nucl. Soc. 20, 598 (1975).

8. M.M. Chaumont et al., "Design of the Core and Subassemblies of a Liquid Metal Fast Breeder Reactor," Trans. Am. Nuc1. Soc. 20, 134 (1975).

9. J. Leclere, et al., "Super-ıhenix Fuel Element Des1gn," Trans. Am. Nuc1. Soc. 20, 308 (1975).

10. "Nuclear Fuel Cycle Requirements," Organization For Economic Corporation and Development, OECD Nuclear Energy Agency, Par1s, France (February 1978).

11. "The Structure and Content of Agreements between the Agency and States Required in Connection with the Treaty on the Non-Proliferation of Nuclear Weapons," IAEA Document, INFCIRC/153.

12. "The Agency's Safeguards System," IAEA Document, INFCIRC/66 Rev. 2 .

13. IAEA Safeguards Technical Manual: Introduction, Part A: Safeguards Objectives, Criteria, and Requirements, IAEA-174 (1976).

14. G. Hough, T. Shea, and D. Tolchenkov, "Technical Criteria for the Application of IAEA Safeguards," International Symposium on Nuclear Materials Safeguards, (IAEA) Vienna, IAEA-SM-231/112 (October 1978).

15. T.Shea and D. Tolchenkov, "Role of Containment and Survelllance in IAEA Safeguards," International Symposium on Nuclear Materials Safeguards, (IAEA) Vienna, IAEA-SM-321/110 (October 1978). 
16. D.0. Gunerson and J.L. Todd, "International Safeguards for Fast Critical Fac1lit1es," Sandia Laboratory, SAND 78-0168 (1978).

17. Indian Point Nuclear Generating Unit No. 2, "Preliminary Safety Report," $\mathrm{NP}-16181$, Vols. 1 and 2 (1965).

18. J.M. McKenzie et al., "Surveillance Instrmentation for Spent-Fuel Safeguards," Sand1a Laboratory, SAND 78-1262 (1978).

19. S. Flarman, M. S. Zucker, A. M. Bleber Jr., "A Laser Surveillance System for Spent Fue1," Proc 2nd Symposium on Safeguards and Nuclear Material Management, ESARDA, Edinburgh, Scotland, March 26-28, 1980, p. 463.

20. E. J. Dowdy, N. Nicholson, and J. T. Caldwe11, "A Nonintrusive Irradlated Fuel Inventory Confirmation Technique," Proc. 2nd Sympostum on Safeguards and Nuclear Material Management, ESARDA, Edinburgh, Scot1and, March 26-28, 1980 , p. 353.

21. D.L. Prezbindowski and D.E. Christensen, "Isotopic Correlation Safeguard Techniques: Reactor Characteristics as Observed from Measured Spent Fuel Data," Pacific Northwest Laboratories, Journal of the Institute of Nuclear Materials Management, p. 21 (Spring 1973).

22. J.A. Carter et al., "A Simplified Method for Preparing Micro-Samples for the Simultaneous Isotopic Analysis of Uranium and Plutonium," International Atomic Energy Agency, Safeguarding Nuclear Materials, Vol. II, p. 461 (1976).

23. S. Ermakov and D. Tolchenkov, "Safeguards Approach For Fist Breeder Reactors (Preliminary Approach)," IAEA-STR-85, May 1979.

24. F. W. Thalgott, "Evaluation of the Safeguards System Propsed for a Fast Breeder Reactor," ISP-Report-73, October 1979.

25. H. Krinninger, C. Brueckner, U. Quandt, E. Ruppert, H. Tschamperl, P. van der Hulst, "Status of the Safeguards System Developed for the LMFBR Prototype Power Plant SNR-300 (KKW Kalber)," Proc. Int. Symposium on Nuclear Safeguards Technology, Vienna, October 1978, IAEA-SM-231/5.

26. N.C. Holtink and C.K. Day, "Under-Sodium Viewing System Development for FFTF," Hanford Engineering Development Laboratory, HEDL-TME-75-103 (1975).

27. S.A. Cox, R.A. Beyerlein, and F.E. LeVert, "Development of an In-Core Directional Fuel Monitor," IEEE Transactions (October 1977).

28. E.A. Hakkila, et al., "Materials Management In An Internationally Safeguarded Fuels Reprocessing Plant," Los Alamos Scientific Laboratory, LA-8042 (April 1980). See also "Coordinated Safeguards for Material Management in a Fuel Reprocessing Plant," Lus Alamos Scientific Laboratory, LA-6881 (September 1977).

29. J.P. Shlpley, et a1., "Coordinated Safeguards for Material Management in A Mixed Oxide Fuel Facility," Los Alamos Scientific Laboratory, LA-6536 (1977). 
30. R. H. Augustson, "DYMAC Demonstration Program: Phase 1 Experience," Los Alamos Scientific Laboratory, LA-7126 (February 1978).

31. C.J. Rodden, Editor, "Selected Measurement Methods for Plutonium and Urantum in the Nuclear Fuel Cycle," (Office of Information Services, U.S. Atomic Energy Commission, 70-74 (1972).

32. H.A. Dayem et a1., "Coordinated Safeguards For Materials Management in a Nitrate-to-Oxide Conversion Facility," Los Alamos Scientific Laboratory, LA-7011 (1977).

33. R.S. Frazer, et a1., "A Safeguards Data System for Sandia Laboratories Plutonium Protection System," Sandia Laboratory, SAND 78-1092.

34. J.P. Holmes, "Conceptual Design of a System for Detecting National Diversion of LWR Spent Fuel," Sandia Laboratory, SAND 78-0192 (1978).

35. W.C. Fienning, A.E. Wimblad (Sandia), and J.P. Shipley (LASL), "A Preliminary Concept Definition for a Mixed-oxide Fuel Fabrication Facility Safeguards System," Sandia Laboratory, SAND 77-0224 (1977). 